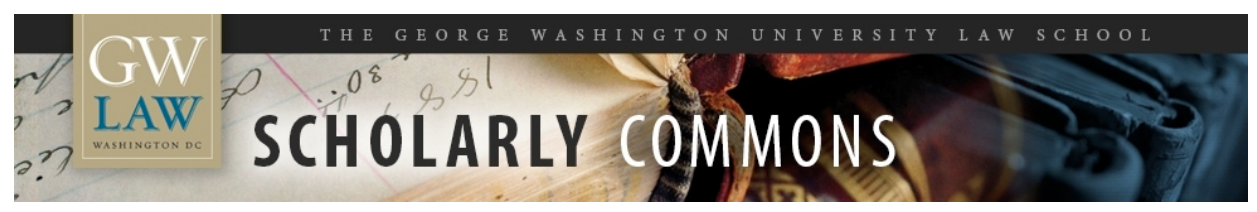

\title{
Owning Versus Renting: Thoughts on Housing Policy, Tax Incentives, and Middle Class Dreams
}

Neil H. Buchanan

George Washington University Law School, neilhbuchanan@gmail.com

Follow this and additional works at: https://scholarship.law.gwu.edu/faculty_publications

Part of the Law Commons

\section{Recommended Citation}

Buchanan, Neil H., "Owning Versus Renting: Thoughts on Housing Policy, Tax Incentives, and Middle Class Dreams" (2012). GW Law Faculty Publications \& Other Works. 40.

https://scholarship.law.gwu.edu/faculty_publications/40

This Article is brought to you for free and open access by the Faculty Scholarship at Scholarly Commons. It has been accepted for inclusion in GW Law Faculty Publications \& Other Works by an authorized administrator of Scholarly Commons. For more information, please contact spagel@law.gwu.edu. 


\title{
Owning Versus Renting: Thoughts on Housing Policy, Tax Incentives, and Middle Class Dreams
}

\begin{abstract}
This document gathers together 22 essays that were originally published as online commentary by Professor Neil $\mathrm{H}$. Buchanan, between 2008 and 2012. All but one of the essays first appeared on the Dorf on Law blog (www.dorfonlaw.org). In these essays, Professor Buchanan discusses the arguments for and against government support of individual home ownership. Most of the essays focus on how to move away from the model of individual ownership. The latter essays, however, begin to embrace the possibility that home ownership incentives should be expanded, to mitigate the current upside-down quality of those subsidies, and to preserve middle-class professional jobs. These essays were also included in the continuing legal education materials for the "Teaching Tax" session at the 2012 Joint Fall CLE meeting of the ABA Sections of Taxation and RPTE in Boston, on September 14, 2012.
\end{abstract}

\author{
Neil H. Buchanan, J.D., Ph.D. \\ Professor of Law \\ The George Washington University \\ Washington, DC \\ nbuchanan@law.gwu.edu
}




\section{Table of Contents}

Two to Tango: Mortgages and Contract Law .......................................................... 1

Monday, August 18, 2008

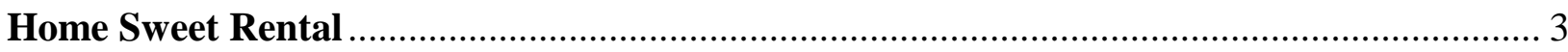

Thursday, August 21, 2008

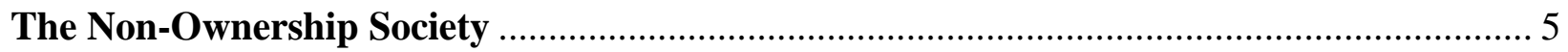

Wednesday, August 27, 2008

Housing and Mortgages -- Dealing with the Crisis ..................................................... 7

Friday, August 29, 2008

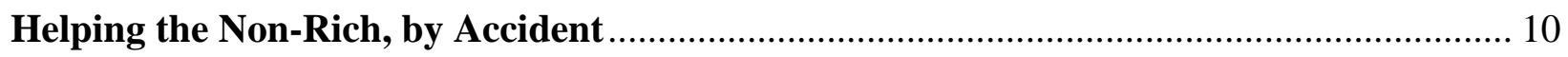

Thursday, January 15, 2009

Big Changes in a Crisis: State and Local Government .............................................. 12

Tuesday, April 21, 2009

Mortgages, Housing, and the American Dream: Do We Really Need to Own Our Homes?15

Thursday, May 28, 2009

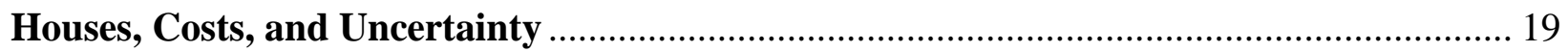

Thursday, May 28, 2009

Some Realistic Suggestions About Owning and Renting .............................................. 21

Thursday, June 04, 2009

A Shift in Washington's Attitude Toward Home Ownership? ......................................... 24

Friday February 18, 2011

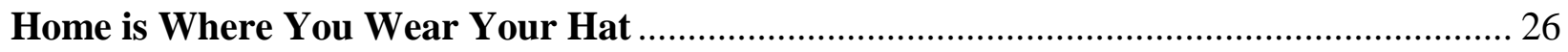

Thursday, February 24, 2011

I Feel So Broke Up, I Wanna Go Home ........................................................................... 29

Friday, February 25, 2011 
If Renting Houses Were a Good Idea, Wouldn't It Already Be Happening?

Thursday, June 02, 2011

Why Have a Bad Landlord When You Can Owe Money to a Worse Bank?....

Friday, June 03, 2011

Owning vs. Renting: Some Not-At-All-Defensive-No-Really Thoughts on Professor

Hockett's Latest Post

Friday, March 02, 2012

Professor Hockett is to Professor Buchanan as a Zebra is to a Unicorn

Tuesday, March 06, 2012

Professor Buchanan Rejoins the Propertied Class

Thursday, May 03, 2012

Private and Public Bureaucracies: Home Ownership Edition

Friday, May 04, 2012

What I Said ... What They Heard

Thursday, May 17, 2012

Leveling Up and Leveling Down: A (Probably Tenuous) Connection Between Home Ownership and Gay Marriage.

Friday, June 8, 2012

The (Somewhat) Hidden Costs of Home Ownership 56

Friday, June 15, 2012

Wasted Talent and the Middle Class

Thursday, August 09, 2012 


\title{
Two to Tango: Mortgages and Contract Law
}

\author{
Monday, August 18, 2008
}

http://www.dorfonlaw.org/2008/08/two-to-tango-mortgages-and-contract-law.html

Here on Dorf on Law, I recently discussed the problem of abusive credit card practices, suggesting that the discussion of whether and how to rein in certain controversial practices by credit card issuers will be distorted by absolutist rhetoric about contracts. "But they agreed!" is likely to be the retort to any suggestion of legal relief for people who signed or clicked through contract provisions that they now wish to avoid. I noted briefly in that posting that this absolutist language of contract carries over to debates about the loan contracts at the center of the current mortgage crisis. Again, the argument is that grown-ups must be held to their agreements, making any provision to modify or set aside contract terms now viewed as onerous a dangerous and paternalistic response.

The presumption in any system of contract must surely be that agreements will be honored. That part is easy. What we often seem to forget is that no system of contract law -- and certainly not ours -- ends at the beginning. The mortgage crisis, in fact, offers a particularly rich set of lessons in how and why some contracts should appropriately be re-written after the fact. (I do not propose to discuss here recent legislation that has been enacted in response to the mortgage crisis. Whatever else one might say, it is safe to assume that recent Congressional action on this issue will not be the last word on this ongoing crisis.)

As a macroeconomist by training, the natural place for me to start is to look at the aggregate picture. When the economy at large is threatened by a problem, averting greater damage is much more important than any particular contract. Just as it is appropriate to take action to prevent the catastrophic failures of large financial institutions ("too large to fail"), it can be necessary to take action to prevent the downward spiral that can come from widespread mortgage defaults ("too many to fail"). Policymakers, of course, will worry about whether the actions that they take today will set a bad precedent for future actions, but a doctrinaire hands-off response to these crises is, thankfully, no longer the end of the story.

The question remains, though, why it is appropriate to ask the non-defaulting party to take a hit in a crisis when it seems to have done nothing wrong. One simple answer is that, sometimes, losses need to be spread around to prevent greater damage. The more interesting answer, though, is that often non-defaulting parties should share in the losses, both because of what they knew when they entered into their contracts and what they did during the contracting process.

A borrower who cannot make loan payments when due is in default. The natural response is to say, "When you entered into the contract, you knew that you had to pay back the loan. You accepted the lender's money in consideration, and now they have a right to a remedy for your breach." Again, as a starting point, this is fine. What we rarely hear is a reminder of what lenders knew when they entered into these mortgage contracts. There are two sides to every contract, it is true, and both sides' actions need to be considered. 
In the case of mortgages -- even mortgages that are not sub-prime -- the "negotiation" between the parties takes an odd form. It is true that mortgages are not "take it or leave it" contracts of the type that we see in the credit card market, with the terms of contracts (especially the interest rate, but also the length, the possibility of penalties for early repayment, etc.) the subject of direct negotiation. In many states, in fact, the buyer must be represented by legal counsel in purchasing a home.

Still, the mortgage process is deliberately set up in a way that makes the borrower a passive participant in the most important part of the process: loan approval. The borrower submits all kinds of confidential personal information to the lender, who takes that information and issues a one-word answer -- approved or denied -- to the applicant. Note that the potential borrower is now an "applicant," waiting for a considered judgment from an authorized expert. Applicants know that their loan will not be approved unless they have enough income or assets or if they fail to qualify on some other objective ground. When they are approved, therefore, there is reason for celebration. "We can afford the house!" The lender has set itself up as having greater expertise (a quite reasonable notion, in the eyes of a borrower), and it has said that the loan is acceptable.

The idea that "you knew what you were getting into," in other words, can just as easily apply to the lenders as the borrowers. Mortgage lenders tell borrowers that their loans are accepted, which a borrower reasonably takes to mean that they will be able to afford the loan. The borrower could have done more to make sure that this was true, but so could the lender. To the borrowers, we often say: "If you didn't want to pay back the loan, you shouldn't have borrowed the money." To the lenders, we must sometimes say: "If you didn't want this borrower to default, you shouldn't have lent them money."

This perspective does not reverse the presumption that loans will be repaid but rather makes that presumption rebuttable. It is a delicate matter to try to figure out how and when contract terms must be voided, altered, or enforced -- so delicate, in fact, that every law school in the world forces its first-year students to study just those issues for at least a full semester. Working out when and how to provide relief to over-extended borrowers is never easy, and the easy answer that they never deserve relief is the least satisfying approach of all. 


\section{Home Sweet Rental}

\section{Thursday, August 21, 2008}

http://www.dorfonlaw.org/2008/08/home-sweet-rental.html

Earlier this week, I posted some thoughts on the ongoing mortgage crisis, describing various reasons why federal intervention is necessary and appropriate given the depth of the current problem and the circumstances under which mortgage loans are arranged. No matter how one feels, however, about the best way for policy makers to respond -- or, for that matter, whether they should respond at all -- this crisis raises a much more fundamental question: Why do so many people take out mortgages in the first place? With so many people facing financial ruin over mortgage deals that they can no longer afford (if they ever could), why are we not asking whether widespread home ownership itself is at the root of the problem?

Now that the recent housing bubble has burst, it seems obvious that too many people who shouldn't have tried to buy houses were approved to take out mortgage loans. One take on the problem, therefore, is that these people were simply not yet ready for the ultimate prize of owning their own home. The current problem is thus just another one of those crazy interludes that occasionally infects financial markets (and that will take years to clean up). Although the bubble years were indeed crazy, however, the problem goes deeper than that. In fact, it is fairly clear that widespread home ownership really doesn't make sense even when there is no crisis. For some people, the numbers add up, but for others it really does not. (This is not, by the way, a matter of income levels. For many middle income and high income people, renting makes more sense than buying.)

See, for example, a web calculator from the New York Times that was posted last year under the headline, "Is It Better to Buy or Rent?" It is fun (in its nerdy way) to plug in various plausible interest rates, resale prices, etc., to see how long one would have to own a home before buying would become financially superior to renting, if ever. Having owned five homes in my life (none for more than four years) before returning to rentals a few years ago, I have played with these numbers quite a bit. It is truly surprising how difficult it is to find a situation in which owning beats renting after less than 8 or 10 years. Given that the average American homeowner moves after 6 years, this says something pretty important about the choices we are making about the biggest purchases of our lives.

What is especially important to notice about these calculations is that the Times's calculator takes into account the tax advantages of home ownership versus renting, the accumulation of equity in the home, etc. It is truly an apples-to-apples financial comparison, including the opportunity cost of putting money for the down payment and a portion of each month's loan payment into home equity instead of interest- or dividend-bearing financial investments. In other words, the usual rhetoric about how "paying rent every month is just throwing money away" (as if interest paid on a mortgage is somehow saved), how "the mortgage interest deduction is the great middle-class tax break," and how "home ownership is the surest way to build up financial security" do not withstand scrutiny. The housing market has generally incorporated the tax advantages into 
prices, and the only financial advantage to home ownership comes from imperfections in the market -- which are legion but which can also cut in the other direction.

If all of this is true, why do people view home ownership as part of the American Dream? (Actually, this mythology apparently extends beyond the borders of the U.S. I was driving through Ontario earlier this summer and saw a sign for a suburban housing development on which a home building company reminded us that it has been helping people "achieve the Canadian Dream for over 30 years.") A big part of the story is direct government policy. The mortgage interest deduction, the deduction for state and local taxes, support for Fannie Mae and Freddie Mac, direct subsidies for loans and first-home purchases, etc., are all based on the idea that home ownership is the ultimate goal of adulthood. That this system creates huge economic problems, including the tying of people to pieces of property even when there are better and more productive job opportunities elsewhere, is left out of the celebration of white picket fences and apple pie.

This is also a particularly good example of how preferences are largely a social creation, not something that people come upon merely through private cost-benefit analyses. Everyone wants to buy a house because everyone else says that they should. Without such an array of social and policy signals, the hassles and perils of home ownership would surely be a lot clearer.

By this point, the cult of home ownership is so ingrained into the nation's psyche and policies that it should only be unraveled with a great deal of attention to the dislocations that would come from a mass movement away from individual home ownership. Given that just the current crisis alone is going to cost us -- privately and publicly -- trillions of dollars and millions of ruined lives, though, it is important to get started. 


\section{The Non-Ownership Society}

\section{Wednesday, August 27, 2008}

http://www.dorfonlaw.org/2008/08/non-ownership-society.html

In my most recent post, I pointed out that -- contrary to widely cherished assumptions -- the supposed financial benefits of home ownership, compared to renting, are minimal to nonexistent. Even taking into account the tax advantages from deducting mortgage interest and property taxes (the latter of which are disallowed for taxpayers who must pay the Alternative Minimum Tax), it turns out that many (even most) people could do just as well or better financially by renting their residences. Putting money into home equity is, for many people, worse than paying rent and putting their savings into other financial instruments. This is, of course, shocking news to Americans who have been told repeatedly that there is no better investment than their homes.

There is an additional financial disadvantage to home ownership that I did not emphasize. Buying a home violates the bedrock principle of safe investing: diversification. No responsible financial advisor would tell the average person to buy shares of just one company, or to put all of their money into a business venture with friends who want to, say, open a restaurant. In fact, one of the little-appreciated problems with $401(\mathrm{k})$ plans is that too many workers put all of their money into the stocks of the company they work for. (Insert bitter Enron comment here.) Nevertheless, our social norms and explicit policies encourage people -- all but beg people -- to pass up a diversified portfolio in favor of putting all of their money into one big asset. If that asset tanks at the wrong time, life is not good.

Even if people are wrong about the financial advantages for buying versus renting, however, it is still possible that there are other benefits of home ownership that outweigh the net financial benefits that renting would bring. Unfortunately, the supposed social benefits of home ownership are at best overstated, and their are other disadvantages to widespread home ownership that cut even further against the idea that everyone should own their homes.

Other than those mythical financial advantages, probably the most common argument in favor of policies to encourage home ownership is that home owners are more responsible than renters, creating more stable neighborhoods. The basic notion is that renters are rootless while home owners stay in one place for the long haul, giving only the latter the incentives to engage with their communities. In part, this is based on a misreading of the simple fact that younger people move around before they settle down and (mostly because they have low incomes and no money for down payments) are renters. The correlation between renting and rootlessness is, therefore, not proof that homeownership will cause people to settle down. In fact, as I mentioned in my previous post, the average home owner in the U.S. sells and moves after only six years. The rock-solid home owners living in the same house from age 25 until they enter a retirement village are anything but the norm.

Still, renters move more often, right? Not necessarily. In places where renting is a meaningful 
option for similar residences, meaning mostly in big cities, people often rent one residence for decades at a time. Many people who grew up in New York City, for example, lived in the same apartment from birth through college (and their parents continue to live in the same place). Many European cities have much lower rates of home ownership, yet neighborhoods are quite stable. People plant flowers in window boxes, neighbors look out for each other's children, crime is low, and all is right in Ozzie and Harriett's world. By contrast, when a person buys a home and knows that she will be leaving in a few years, there is little reason to become engaged with the local schools, community issues, etc. (My personal experience is unique, of course, but having owned five different houses for periods ranging from 18 months to 4 years, I can testify that owning can feel just like renting. From Fox Point, Wisconsin, to South Orange, New Jersey, I never attended a town hall meeting or joined an Elks Lodge.)

In other words, while the question of neighborhood stability is ultimately an empirical one, there is at least strong reason to suspect that we can have very stable neighborhoods without everyone being on the hook for a huge mortgage. When people stay put (or, more accurately, when they expect to stay put), they take the time and effort to invest in their surroundings and to become part of the community. This suggests that landlord/tenant laws are as important to neighborhood stability as mortgage interest deductions. Probably more so.

Moreover, as I pointed out in my most recent post, one major social and economic cost of home ownership is precisely that it ties people down. In the depths of the recession of the early '80s (the worst downturn since the Great Depression), President Reagan encouraged people to "vote with their feet," since there were relatively plentiful jobs in the Sun Belt even as the Rust Belt was earning its new nickname. This was fatuous, because the people in Michigan, Ohio, and Pennsylvania who might have moved to Arizona and Texas were financially tied to homes that had become nearly impossible to sell without the owner losing everything.

The economy, therefore, significantly underperformed because too many people owned their own homes. (Put another way, risks in the housing sector were not spread efficiently.) This, by the way, would be true whether or not there is a net increase in rootedness due to home ownership. That is, even if there is no difference in mobility between home owners and renters during non-recessionary times, the difficulty of selling for owners during downturns harms the labor market as a whole.

This discussion, of course, hardly covers all of the issues. (Among other things, there are serious environmental and energy-use problems associated with U.S. housing patterns.) Still, taken as a whole, it is quite surprising that home ownership continues to be held out as an unambiguous benefit to families, communities, and America.

In the next episode of what has become a series on the topic of home ownership, on Friday I will discuss the current mortgage crisis and why -- even though it was a bad idea to encourage so many people to buy their own homes -- it is essential for policymakers to continue to try to minimize and undo the damage that the current wave of foreclosures has caused. 


\title{
Housing and Mortgages -- Dealing with the Crisis
}

\author{
Friday, August 29, 2008
}

http://www.dorfonlaw.org/2008/08/housing-and-mortgages-dealing-with.html

In a series of recent posts (on August 18, August 21, and August 27), I have discussed housing policy in the United States in the context of the current mortgage crisis, a crisis that began with the excesses in the subprime sector but that has now spread into the rest of the housing market and the financial sector as a whole. The two most recent of those posts were mostly devoted to: (1) disproving the myth that home ownership is the key to financial success for average Americans, and (2) showing that home ownership is not the only way to create safe and stable neighborhoods. Owning one's own home has become something that every politician extols, employers encourage, the tax code subsidizes, people write songs about, and just about everyone believes should be the goal of a good society. It is genuinely surprising, then, that the benefits of home ownership are so overstated and the costs so ignored.

One possible conclusion to this line of posts would be to say, "Well, now that the party is over, the best thing to do is let the chips fall where they may. To the extent that specific policies have encouraged home ownership, the best thing to do is to repeal those policies immediately. In any event, too many people are in homes that they shouldn't own; and the last thing we should do is help them stay in those homes." As I have suggested in those earlier posts, however, I do not take that view. The current post-bubble disaster in housing calls for an aggressive policy response, in an effort to minimize the number of people who will lose their homes.

This seemingly paradoxical position -- advocating policies in favor of current home owners, even though I believe that they never should have bought houses in the first place -- is based on the simple idea that policy should be based on an assessment of where we are, not where we wish we were. If we could go back in time, I (like almost everyone else) would have done things differently -- in this and in so many other areas of national policy. (Iraq, anyone?) We cannot, however, simply pretend that there is no crisis just because we know how we might have avoided it in the first place. While it is possible that the right response among the entire range of policy responses is to "let 'em rot," in this case I agree that doing nothing would turn a terrible situation into an all-out disaster.

The Home Owners in or Near Default -- The place to start is with the people who stand to lose their homes. Many of them were approved for mortgage loans that made sense (even from the lender's perspective) only if housing values continued to climb at unsustainable rates. As I argued last Monday, however, these new home owners were hardly the well-informed bargainers that classical contract theory assumes. The mortgage approval process is set up to make people believe that they can afford homes if they are approved for a mortgage. Moreover, I do not believe that people are immune to the hype that surrounds home ownership in this country (and others). To a large degree, millions of people bought homes because we collectively told them that that was the patriotic (and financially wise) thing to do. Telling them now to deal with it on their own evokes a line from the now-classic comedy "Animal House": "You f_cked up. You 
trusted us!!"

This does not mean, of course, that mortgage loans should simply be erased. It does suggest, though, that there is good reason to try to allow as many people as we reasonably can to stay in their homes. The consequences of default and eviction include thousands of dollars of expenses at a time when people can least afford it, destroyed credit ratings, and often destroyed marriages and personally destructive behaviors. This is not something to take lightly, even if we wish that these people had not been so eager to buy their piece of the American Dream.

Other Home Owners -- Whether or not one feels the same level of sympathy as I do about the defaulting home owners themselves, the simple fact is that the rest of us are at risk if policymakers do not smooth out this crisis. People who have done everything right -- buying a house that they could clearly afford, signing mortgage papers after diligently reading every word on every page, making payments on time and in full -- stand to lose because of what is going on around them. Most obviously, those who currently need to sell their homes because they need to move to a new job or for any other reason could easily lose everything. Given that even safe mortgages are made on $80 \%$ of the house's value, a drop of $10 \%$ in housing prices wipes out half of an owner's equity in a home. When defaulting home owners flood the market, the downward spiral takes other home owners with them. Stopping that spiral can mean the difference between an innocent home owner's being wiped out entirely or "merely" losing a huge chunk of her net worth.

Just as seriously, the external costs of widespread housing dislocation go beyond financial losses. Communities around the country find themselves looking at neighborhoods in which half the homes are suddenly empty. This causes increases in crime, as criminals find it easy to move into empty homes. (When I owned a home in Ann Arbor a few years ago as an absentee landlord, my renters moved out. I asked my insurance company to change my policy to cover the empty dwelling while I tried to sell it. I discovered that there was no insurance company that would insure -- at any price -- an empty home for more than a couple of months. The risk, even in an otherwise fully populated neighborhood, was deemed "uninsurable.") People whose only sin is living in a neighborhood where half of their neighbors defaulted find that they cannot win either way. If they try to sell, they cannot sell their homes without themselves defaulting on their mortgages. If they stay, their neighborhoods are unsafe for their families to live in.

The Economy and the Rest of Us -- Even those of us who do not live in neighborhoods that will be affected by declining home values have much to lose from the current crisis. When banks and other financial institutions fail -- even when their failures are, as is so often the case in the current instance, due to poor internal management of risks -- it affects the rest of the economy and puts the entire financial system at risk. Loans for sound investments become harder to get, equity in formerly good institutions disappears, and it becomes essential not to let things get further out of hand. In Japan, for example, a once-roaring economy was choked by a real estate collapse in the early 1990's. That country is only now recovering from almost two decades of recurrent recessions and depressed economic activity. Thankfully, U.S. policymakers have understood that we have too much at risk to let that happen here.

The exact contours of the appropriate policy response to the current mortgage crisis are well 
beyond what one can describe in a blog post. My point here is simply to say that even someone like me who thinks that the long-term best policy is to encourage people to be more realistic about the choice between home ownership and renting can still see the importance of an aggressive policy to keep as many people as possible in their homes right now. Ultimately, this is in everyone's best interest. 


\section{Helping the Non-Rich, by Accident}

\section{Thursday, January 15, 2009}

http://www.dorfonlaw.org/2009/01/helping-non-rich-by-accident.html

One of the most politically sacrosanct benefits available to taxpayers is the deduction for home mortgage interest. Along with the deduction for state and local taxes, this benefit expresses a longstanding and bipartisan policy preference to encourage home ownership in this country. Whether the net result of these tax benefits is actually to increase home ownership is a separate question, but there is no doubt that politicians view this benefit as untouchable. In fact, when in 2005 President Bush created a commission to make recommendations for fundamental reform of the federal tax system, he made abundantly clear that any recommendations must include tax incentives to encourage home ownership. (The panel did so, although their entire report was ultimately ignored by lawmakers.) There seems to be nearly unanimous political support for the idea that the tax code should make us a nation of homeowners.

Who is really helped by these pro-homeowner tax benefits? Last week, at the annual meetings of the Association of American Law Schools, Professor Dorothy A. Brown of Emory Law School offered a fascinating discussion of the effects of these federal tax benefits on low-income and minority homeowners. She showed, among other things, that a surprisingly large number of such homeowners receive no actual benefit from the deductions for mortgage interest and property taxes, because they do not itemize their deductions. As Dorothy demonstrated, this means that the tax code only benefits some homeowners while leaving those with lower incomes and less expensive houses out in the cold. She thus showed that the system currently provides benefits in a regressive fashion, and she argued that "this cannot stand."

I completely agreed with Dorothy's motivations (as I almost always do), and I found her argument to be thought-provoking. Because of my belief (see here, here, and here) that expanded home ownership should not be a goal of public policy, however, I asked Dorothy two questions during the Q\&A. First, I suggested in essence that we should address the inequality that she had identified by "leveling down" rather than "leveling up." That is, rather than following her suggestion that we should make sure that the tax benefits for home ownership are available to all homeowners, we should instead take them away from all homeowners. She suggested in response that (beyond the political impossibility) there would be difficult transition costs in such an approach, which is true but (in my opinion) not insurmountable.

My second question, which Dorothy unfortunately was not able to address due to time constraints, was whether the current system is not actually (and completely inadvertently) beneficial to low-income and minority citizens. That is, since home ownership is a very bad way to save money (not only during a dramatic crash like the current crisis but more generally because building home equity is the very definition of undiversified investing), and since lowincome people are the least able to cope with the loss of their home equity (since they almost never have any other significant amounts of money saved in any other form), a tax system that leaves out the low-income taxpayers is actually doing them a favor by not encouraging them to 
own a home.

Therefore, although my first choice would be for the government to completely change course and discourage individual home ownership, the current system -- which seems to disadvantage those with less income and wealth -- might be a better alternative than to adopt a plan to eliminate that supposed disadvantage. This outcome thus works, by sheer luck, as the equivalent of a progressive tax policy to steer the most financially vulnerable away from possibly ruinous risk-taking.

I have to admit that I am somewhat uncomfortable with my own conclusion. There is something unsettling about this "cruel to be kind" approach to social policy. Still, if the choice is to leave things as they are or to change the tax code such that it would encourage more lower-income and minority citizens to buy homes, I think I would choose the former. 


\title{
Big Changes in a Crisis: State and Local Government
}

\author{
Tuesday, April 21, 2009
}

http://www.dorfonlaw.org/2009/04/big-changes-in-crisis-state-and-local_21.html

Late this past December, I inaugurated what I hoped would be a series of posts discussing some large changes that we could make in various areas of the economy and society, changes that might only be possible in a time of severe crisis. I did not realize it at the time, but the basic idea was captured by Rahm Emanuel, soon to be the chief of staff of the Obama White House, in his pithy observation that "you never want a serious crisis to go to waste." Some interests are so entrenched that our only hope for ever dislodging them is to ride the wave of an era-defining change in attitudes and expectations.

After my initial promise to write that series of posts, I wrote one post in which I discussed changing the automobile industry in the United States to be more environmentally responsible and customer-friendly. I then let the "big changes in a crisis" series lapse, in part because of the whirl of news and events surrounding the new administration, but also in large measure because it seemed that the Obama administration was taking to heart Emanuel's suggestion to think big. If anything, in fact, President Obama has been criticized for thinking too big about too many things, criticism that might tend to prove that the current crisis is not so severe as to have shaken loose the do-nothing tendencies in the political culture. Even some of his medium-sized (but very good) ideas, such as his plan to limit the tax deductibility of various items for higher-income taxpayers (which I discussed here and here), have already been beaten into submission.

Moreover, there are some big ideas that become less desirable (or politically plausible) during a big crisis. My strong preference that the country move away from home ownership and toward stable rentals of both apartments and houses (discussed here and in posts linked therein) is rightly not on the table, given that the collapse of home-building is one of the major reasons that the economy tanked last year and that there is no plausible substitute for a rebound in the housing industry as a necessary part of bringing the economy back to health. (Disclosure: My mother's father and brother were home builders, so I was partly reared on concrete blocks and $2 \times 4$ 's.) Changing the mix of owning and renting is an important project that could bring major benefits to middle-income families, but this must be a slow process that begins during relative prosperity.

Even so, it continues to be important to think about what can be done during a time that uniquely calls out for big thinking. In a guest editorial in yesterday's New York Times, the journalist Tom Brokaw suggests that it is time to re-think the number and organization of sub-state governments. (Brokaw is no more qualified to opine on this subject than any reasonably wellinformed person, but why question the parentage of a good idea?) Brokaw suggests, in a nutshell, that there are simply too many county and municipal governments and school districts in this country and that it is time to combine them in a way that could save huge amounts of money. (He does not offer any numbers regarding plausible savings, and I would welcome comments pointing toward any estimates that have been made along these lines.) Doing so now might be 
possible because the states are having even more severe financial shortfalls than they usually face during an economic downturn, so that the same legislators who are reconsidering their previous embrace of get-tough prison expansions -- and even the death penalty -- on financial grounds might finally decide that it makes no sense to keep so many small-town mayors, police chiefs, and school superintendants on the job.

The problem of too many local governments is a classic example of simple institutional inertia. As the country grew, towns sprouted, and local governance was the norm. Brokaw talks about Iowa's 99 counties and the absurdity of the regional university system in his native South Dakota. Growing up in Ohio, I knew that there were 88 counties, most of which were less populated than my high school home room. When I lived in New Jersey several years ago, one of the most perplexing questions was why the state was continually in a budgetary crisis even while it was the most heavily taxed state in the country (and even while its highly educated and wealthy population should have been able to easily outweigh its urban poor in a budgetary sense).

True, New Jersey is legendary in its tales (and reality) of political corruption; but other states have plenty of corruption as well. What makes New Jersey's government more expensive to run than, say, Illinois' or Texas' or New York's? One explanation was that New Jersey supports more local governments and school districts than any other state. Even after living there for a couple of years, I was constantly amazed to discover on a very regular basis yet another town nearby of which I had never been aware. It was something of a miracle that my town, South Orange, shared a high school with its neighbor Maplewood, since there seemed to be a state-wide allergy to combining any local services.

Brokaw points out that New York State not only has its own version of this problem but that a bipartisan commission has already offered a list of suggestions to modernize sub-state governance and thus to both save money and rationalize an absurdly scattered and inefficient system. Given that New York is one of the states with an especially acute fiscal crisis (driven by its dependence on the financial sector, which is obviously one of the most depressed parts of the U.S. economy), one would think that politicians there would be especially open to big changes that could save money. Yet the commission's recommendations apparently have little chance of being adopted.

Why would this be so? One possibility is that state-level politicians were once local politicians, which inclines them toward protecting their roots and the friends they left behind. There ought to be at least some element, however, of embarrassment and contempt among those who have "made it big" for their grimy past, which might counterbalance the desire to preserve the old ways with a desire to prove that one is now above all that. A more likely explanation is that statelevel office is not far enough away from the local and county levels to allow state legislatures to act independently. The same people who keep a state legislator in office have interests in county commissions and town councils. (Another explanation is that one should not cut jobs, even duplicative local government jobs, during a recession. That, however, is a reason to phase out the jobs, not an excuse to do nothing.)

This should not be a reason to despair. Any political system, public or private, is going to be 
filled with people who resist change. (See any law school faculty.) The longer this crisis continues, the more hope there is that it will result in at least some reform in our wasteful and antiquated systems of local government. That is not a reason to cheer on the economic decline, of course, but it gives us one more way to direct our energies toward improving our society going forward. 


\title{
Mortgages, Housing, and the American Dream: Do We Really Need to Own Our Homes?
}

\author{
Thursday, May 28, 2009
}

http://writ.news.findlaw.com/buchanan/20090528.html

As many readers well know, the current economic downturn is closely tied to problems in the housing and mortgage markets. The bursting of the housing bubble led to the subprime mortgage mess, followed by widespread losses in the financial markets, the collapse of once-solid financial institutions, and a once-in-several-generations recession that might still become a depression. Moreover, the subprime problem is now reportedly being followed by a wave of mortgage defaults and foreclosures of homes owned by people who are losing their jobs, threatening to set off another round of financial chaos.

These are indeed trying times, and it is understandable that policymakers are trying to do everything possible to prevent homeowners from losing their homes to foreclosure. The question that we seem to be avoiding, however, is whether the current crisis points to a larger problem not just in our financial markets but in our commitment as a society to encourage home ownership.

This might be the right time to step back and ask: Why do we try so hard to increase the number of people who own their own homes? It might be time to change ourselves into a nation of renters - not as a response to hard economic times, but because it really is a better idea for most people not to own their own homes.

\section{Questioning a Proposition Near and Dear to Americans' Hearts}

There is no doubt that this is heresy. The very notion of the American Dream includes the idea that two people marry, start a family, buy a house, pay off the house over the space of thirty years, and retire on the equity in that house. (This notion, moreover, is apparently not limited to the U.S., as I once saw a sign in Ontario for a home builder who has been helping people "achieve the Canadian Dream for over 30 years.")

In order to encourage people to start down that well-worn path, we offer tax deductions for interest on home mortgages (but no deductions for rent), we exempt the value of owner-occupied housing from taxation, and we have created extensive loan programs to finance mortgages. Perhaps more importantly, we have surrounded ourselves with a mythology that directly connects the idea of being an independent adult with a person's status as a homeowner.

Why do we put so much stock in the idea that people should own their own homes? One important justification has always been that home ownership provides needed stability to neighborhoods, based on the idea that people have a greater stake in their communities when they own property, giving them a reason to join the PTA, run for city council, and generally be a good citizen. Renters, by contrast, are seen as rootless wanderers. With such a stark contrast 
between our images of owners and renters, it is no surprise that policy has been driven by the idea that we need to encourage people to take the plunge and buy a house.

\section{The Case for Home Ownership Is Far Weaker than Has Often Been Assumed}

It turns out, however, that the justifications for encouraging home ownership are questionable at best. Even with the levels of home ownership that we see in this country, it turns out that people only live in their homes for a median of six years. Serial home ownership is thus the norm, and the supposed benefits of stable neighborhoods and citizens committed to the long-term health of their communities is difficult to square with the reality that people sell their homes quite frequently.

Even with all of the cultural pressure to own homes, people understand that home ownership is really just another form of renting. No wonder we often hear the sardonic comment, "I don't really own my house. The bank owns it and lets me live there." And indeed, home owners have traded one form of payment for another, and they have paid for the right to do so with a large down payment, high closing costs, and the knowledge that the process of moving will be much more difficult than it ever was as a renter.

Moreover, the supposed financial benefits of home ownership are hardly clear-cut. People talk about the tax advantages of mortgages as if there is no possibility that renting could still be a financially superior option. Even with that tax advantage, however, it is still quite possible for renting to be financially superior to buying. The New York Times, for example, has made an online financial calculator available to answer the question: "Is It Better to Buy or Rent?" Even assuming that the market for resale is steady - and even taking into account all of the tax and financial advantages of home ownership - it can take well over ten years for buying to surpass renting on a financial basis. For people who expect to move over much shorter time horizons (and that includes most of us), renting can be the much smarter choice.

\section{The Recent Irony of Home Ownership: A "Safe" Choice Proves Disastrously Risky For Some}

The current reality, of course, is that the market for selling houses has been anything but steady. People who dutifully spent years building equity in their houses, never missing a payment and even accelerating the payoff of their mortgages, are finding that they have lost money by owning a home. They also are finding that a factor that is not under their control at all matters very much: If neighbors abandon their homes, the neighborhood can become dangerous, with home prices taking a huge tumble.

This is the cruel irony of home ownership. People were given good reason to think that they were being smart by buying, only to learn that putting all of their eggs in one basket exposed them to catastrophic risk. This is the kind of investment strategy that no sensible financial planner would endorse, because it is the exact opposite of spreading risk. Diversified portfolios are safer than single investments, yet everyone closed their eyes and believed that this rule somehow does not apply if the single investment is a house. 
There are, in fact, good reasons why the risk is actually greater in housing than in other types of investments. If the underpinning of the local economy dies (as in, for example, Michigan), who is going to buy a seller's home, even after the rest of the nation's economy recovers? In addition, as an article in The New York Times recently pointed out, many of the people who have lost the most in the current housing bust are the very people who have traditionally been shut out of the housing market, particularly minorities. Once they were finally allowed to partake of the American Dream (even on a non-subprime basis), the dream for these citizens became a nightmare.

\section{The Arguments for Home Ownership Carry Some Weight, But Are Not As Strong As They May Seem At First Glance}

Despite all of this, there are still reasons why people choose to own homes. One is the idea that owners can do things in and to their homes that renters cannot. Owners can decide whether to own pets (and how many), whether to paint the living room purple, whether to finish the basement, and on and on. The freedom to make these decisions without apparent limit draws many to the idea that there really is nothing like owning one's home.

Again, however, reality is at odds with the myth. Rentals can be found that allow pets. In fact, everything that one can do in a house can be done in a rental. The difference is that the renter will be given an explicit price up front for doing what she wants, whereas the cost of doing what one wants to a house is hidden until the house is up for sale. (Many homeowners have ruefully discovered too late the consequences of poor upkeep, bad design and fashion choices, and an unfortunate lack of curb appeal.)

The difficulty in thinking about a world with a lot more renting and a lot less individual ownership is that the market for certain kinds of rentals is currently quite thin. If policies were changed to encourage property managers to aggregate ownership of homes, then they could begin to take advantage of their ability to spread risks and to provide services on a scale that individual homeowners cannot hope to replicate. (Anyone trying to find a reliable handyman knows how chaotic the market for home services can be.)

Indeed, this process is already beginning to happen in some parts of the country, even without support from policymakers. In Phoenix, which has experienced extremely large decreases in home prices, reports indicate that entrepreneurs are buying homes out of foreclosure and renting the houses back to the prior owners. Apparently, the people currently engaged in these transactions plan to sell the houses back to the owners as soon as possible, but that is not necessary. With the appropriate incentives, we could expand the opportunities for people to live in single-family homes without putting their financial lives at risk.

For this process to move forward, we would need not only to change our attitudes about what constitutes "being a grown-up," but also to think seriously about the legal challenges that would arise with a move toward large-scale middle-class home rentals. Landlord/tenant laws would surely need to be scrutinized carefully to see whether they are adequate to deal with a world that is not driven by year-to-year leases and renters who are often financially marginal. 
While mainstream economists typically disapprove of rent controls, for example, there should at least be options in place to allow people to lock in long-term rental contracts. One littleappreciated benefit of long-term rentals is precisely the increase in stability that comes from knowing that one will not face a big rent hike over a reasonable span of time, allowing people to settle in and become part of the community. Some of New York City's most stable neighborhoods include large numbers of renters who live in the same place for decades. The key issue is not owning-versus-renting, but staying-versus-leaving.

For this change to occur, policymakers in Washington and in the state capitals would have to come to realize that our emotional commitment to home ownership has cost us individually and as a society. We can still choose where to live and how to live, but we need not risk everything in order to do so. 


\section{Houses, Costs, and Uncertainty}

\section{Thursday, May 28, 2009}

http://www.dorfonlaw.org/2009/05/houses-costs-and-uncertainty.html

I have another guest column on FindLaw this week, "Mortgages, Housing, and the American Dream: Do We Really Need to Own Our Homes?" to be posted later today (here). In that article, I pick up on my Dorf on Law posts from last August (here, here, and here) to argue that the United States should move away from its fixation on the idea that success in life must include owning one's own home. Here, I would like to expand on a point that I make only tangentially toward the end of that column: "In fact, everything that one can do in a house can be done in a rental. The difference is that the renter will be given an explicit price up front for doing what she wants, whereas the cost of doing what one wants to a house is hidden until the house is up for sale."

The more I think about those two sentences, the more I am shocked that Americans think about owning their homes as being fundamentally different from renting. If there were a market for rentals (including house rentals, not just apartments) that was both broad and deep, renters and owners would be able to negotiate intelligently (and with alternatives) over virtually every aspect of living. Do you want to be sure that your rent will not rise for ten years? You could either sign a ten-year lease or negotiate a contract that would value the guarantee appropriately while allowing you to move out in less than ten years. Do you want to add a room to the back of the house? You and the owner could split the cost based on the length of time that you expect to live in the house, taking account of the change in the value of the underlying property. Multiple pets would be an easy issue, as would design choices, landscaping, and pretty much everything else.

The reason that this is so shocking, once one thinks about it, is that people have convinced themselves that owning their homes puts them in a fundamentally different position because they can do "whatever they want" as owners, whereas they are slaves to their landlord as renters. The simple fact, however, is that doing what one wants always has consequences. Add a room? The homeowner carries the cost of financing (either the interest cost on a loan or lost income from otherwise investing the money) and the risk that the room will not increase the underlying value of the home when they need/choose to sell. The big difference, again, is that in a rental agreement an owner (who, presumably, would own multiple properties in order to spread risk) would let the renter know the cost of each decision up front.

The bigger society-wide gain from allowing ownership of homes to be separated from occupancy, of course, is that owners of multiple properties are less likely to find themselves in a must-sell mode than an individual owner who might have been transferred to a new location on short notice. The risk in the system would thus be distributed in a way that would reduce the likelihood of net-worth-destroying losses if a sale must be made at the wrong time.

None of this is based on an even mildly advanced or controversial theory. This is basic economics, basic finance, and basic contracting. The thing that prevents it from happening is the 
public policies -- and the public attitudes that strongly support those public policies -- that push people into buying rather than renting. Change the policies -- the home mortgage interest deduction, the first-time home buyer credit, the programs that support and expand the availability of mortgage financing -- and the market fundamentals will change. Even though there is no law saying, "You may not rent a single-family home," the laws that do exist push people into ownership and thus shrink the potential market for rentals to the point where it is simply too small to develop reasonable market norms and equilibrium prices that reliably reflect underlying values.

What makes this especially interesting is that changing the system would be entirely a matter of law. That is, unlike ideas to, for example, change the transportation system to discourage automobile ownership and encourage the use of public transportation, changing the norms of home ownership versus renting does not require billions of dollars worth of public investment in a new or different infrastructure. If the laws were changed, people would begin to develop market transactions that would spread risk while allowing people to continue to live in the existing housing stock.

As breathlessly optimistic as all this might sound, of course, the cold reality is that "merely" changing the laws regarding home ownership is in some ways more daunting than building a network of high-speed rail lines. It would be futile for me to make a proposal along the lines that I have described here to any politician. Social Security used to be thought of as the "third rail of American politics" (touch it and die), but the social norms that extol the virtues of owning one's home make that look like child's play. As I said in response to a comment on one of my posts last August, this idea is surely a political non-starter, but "[t]hat's what tenure is for!" 


\title{
Some Realistic Suggestions About Owning and Renting
}

\author{
Thursday, June 04, 2009
}

http://www.dorfonlaw.org/2009/06/some-more-realistic-suggestions-about.html

Last Thursday, I continued my jeremiad against individual home ownership. The essence of my argument is that the social pressure to own a home -- pressure that is reflected in many different public policies -- is harmful to both individuals and society in ways that go far beyond the immediate housing-initiated economic crisis. Because of my professional habits, I focused on the tax advantages conferred on home ownership and suggested that we should eliminate those advantages if we want to solve the underlying problem. Today, I will begin to explore some politically realistic ways to deal with the problem.

To summarize, the biggest problem with individual home ownership is that it concentrates risks in ways that can be ruinous to people whose homes lose value. Moreover, this personal tragedy can become a problem for the rest of the country when people are, to put it simply, stuck where their houses are but the jobs are not. Also, as one of the comments on my recent post noted, the long-term average annual rate of return on a house -- over a long enough period to smooth out the cyclical factors -- is on the order of $1 \%$. Even without bad luck in the timing of a sale, this is not a great way to invest. Yet we continue to encourage it.

In two of the tax-apalooza sessions at the Law \& Society conference last weekend, the wisdom and political salience of the mortgage interest deduction came up for discussion. In one session, UC Davis's Dennis Ventry presented a paper whose title says it all: "The (Ignominious) Rise and (Predicted) Fall of the Home Mortgage Interest Deduction." Ventry's analysis focuses on the political history of the deduction, but as a normative matter, it seems fair to say that his scholarly analysis confirms what I have written here and on FindLaw about the foolishness of allowing a tax deduction for home mortgage interest.

While Ventry predicts the eventual repeal of the deduction, however, I was caught short by a comment at another session. Discussing the history of California's property tax revolt that led to Prop 13, a political scientist commented that the mortgage interest deduction was incredibly important to her personally and stated quite emphatically that, if it were taken away, there would "be a revolt." If even well-trained academics are this viscerally attached to the tax deduction, it is probably worthwhile to think about ways to mitigate the harms of individual home ownership other than through the elimination of existing tax advantages.

As an initial matter, as the last commenter on my post last Thursday also pointed out, it should be possible to solve the problem not by discouraging individual home ownership but by making it less harmful to individuals and society when homes lose value. Theoretically, it should be possible to insure against losses in the price of one's home in a way that spreads those risks, just as insuring against all other perils can spread risk. Encouraging "loss in housing price insurance" would thus be one way to make it possible to own one's own home without really having all one's financial eggs in one basket. 
As it stands, however, that market has clearly failed. If we can make it work better, then we could allow people to indulge their desire to own their castle without putting themselves and society at risk. If we cannot do that, however, we need to think about other ways to prevent people from wanting to buy homes when they really should not be a homeowner. How might that work?

First, as a matter of public education, it is surely worth publicizing the fact that the home mortgage interest deduction (and the deduction for property taxes, for those who are not subject to the Alternative Minimum Tax) do not automatically make home buying superior to renting. In many if not most markets, the price of homes has fully "capitalized" the value of the tax deductions -- that is, the price of the house itself has risen to reflect the value of the tax deduction, so that the buyer has the same net monthly payments that she would have if there were no tax deductions (and lower house prices). Letting people know that owning one's home is not a "special deal" would surely move us in the right direction.

This also, by the way, suggests that eliminating the tax deductions might have an effect on home ownership only inasmuch as doing so would make a symbolic statement about the value of home ownership. If the elimination of the tax deductions would (after the transitional effect of lowering the prices of existing homes, losses that would need to be compensated in any plan to change the tax laws) not change the actual cost of owning a home, then the only way that such elimination could shift people into rentals would be to send the message that "society no longer thinks that home ownership is importance enough to subsidize." Again, however, the counterintuitive nature of such a symbolic statement is what would surely derail attempts to enact the desired change in the tax laws.

Even if we cannot discourage home ownership directly, however, we can surely start to enact policies that would make rental markets operate more smoothly. This is a situation where the thinness of the market is the essence of the problem. In that way, it is like the issues that arise with veganism, as I pointed out in two posts last summer. When there are too few potential buyers of a particular type, there is no reason for sellers to accommodate that group of buyers; but when a critical mass is reached, the situation can improve "on its own" dramatically. The role for public policy, therefore, is to try to push the market in a direction that will allow it to become deep enough and mature enough that the only role for public policy going forward would be to maintain the background rules of contract law, public health, etc.

As another comment on last Thursday's post pointed out, the current transaction between landlords and tenants looks very one-sided. It is surely possible and desirable for the laws governing tenancy to be changed in ways that right that balance. I have suggested in earlier posts, however, that the movement of people who are not financially marginal into the market for renting will itself tend to change the way that landlords act. When I lived in Manhattan, I rented a rather expensive (even by New York standards) apartment; and even though I signed a "take it or leave it" contract, the content of that contract was much more favorable to renters than any rental contract that I had seen before then. The market for luxury apartments there is welldeveloped enough that the existing norms and laws provide an even playing field for renters. 
More directly, even if we cannot eliminate the tax deductions for home ownership, we could allow a federal deduction for any housing-related expense, including rent. Many states already allow this. Again, even if this tax change is fully absorbed into the ultimate prices, the legal equivalence of buying and renting could change the way people view their housing decisions.

Perhaps the most promising possibility, however, is uniquely available to us because of the current housing crisis. With the large number of foreclosures, the federal government has been busily looking for ways to keep people in their homes. It would surely be possible to encourage more lenders to allow people to continue to live in their homes after foreclosure. Even if the lenders do not want to become property managers, targeted incentives should make it worthwhile for them either to begin to do so on their own or to hire property management companies to handle the new renters' needs.

The bigger point is that there appear to be ways around the political inviolability of the tax deductions for home ownership. The essential point that I have been pressing in these blog posts has been that owning and renting are different in form but not substance. Public policies can exploit that equivalence by avoiding the bad public relations of seeming to attack home ownership and instead "expanding freedom of choice." Isn't that the American Dream, too? 


\section{$\underline{\text { A Shift in Washington's Attitude Toward Home Ownership? }}$}

\section{Friday February 18, 2011}

http://www.dorfonlaw.org/2011/02/shift-in-washingtons-attitude-about.html

Early in the financial crisis, I wrote a series of FindLaw columns and Dorf on Law posts discussing and decrying the strong preference in the United States for people to own their own homes. (The most recent DoL post is here. That post includes links to my earlier writings on the subject.) The short version of my argument is that home ownership concentrates families' financial risk in entirely inappropriate (and often disastrous) ways, and that all of the supposed advantages of owning can be achieved in a world of renting.

Even as I argued that Americans' universal preference for home ownership was based on fundamental misunderstandings of the nature of owning versus renting, I acknowledged in nearly everything I wrote on the subject that changing people's attitudes about such a deeply-held ideal would be a nearly impossible task, best left to those (like tenured professors) whose job security should not be threatened by making unpopular proposals. I never imagined that any politicians -and certainly not the hyper-cautious politicians in the Obama administration -- would push in this direction.

To my surprise, however, a report from Treasury and HUD was released earlier this week, in which the administration proposes to get the government out of the business of guaranteeing home mortgages (which it has long done, mostly through Fannie Mae and Freddie Mac). The response has been surprisingly muted, given that one news article described the report's broad message as: "Better to help some people rent." Pretty radical stuff in DC.

Unfortunately, my initial sense that this was a refreshing case of boldness on the part of the administration was undermined by the news that the proposal is most strongly opposed by some of President Obama's most reliable backers, and supported mostly by his opponents. (" 'Gutting Fannie and Freddie is the most irresponsible housing proposal yet from this administration,' said Representative Dennis Cardoza, a Democrat from the Central Valley in California. 'How is Joe Six-Pack ever going to be able to afford a home?' ") As a broad political matter, therefore, this is merely more triangulation from the neo-Clintonites.

While I understand why liberal groups have generally supported home ownership initiatives, however, I think that they are ultimately wrong. (Meanwhile, the reasons that most conservatives oppose Fanny and Freddie are even more wrong.)

The major impetus behind this proposal is, of course, the cost of the Fannie/Freddie bailouts to the public Treasury. An editorial in yesterday's New York Times, for example, assessed the report's three alternative proposals to reduce or remove federal mortgage guarantees, focusing its analysis entirely (and, in the context of the Great Recession, appropriately) on how likely each proposal would be to lead to future financial crises and public bailouts. Notably, however, the Times's editors expressed concern that "moderate-income communities could still be left 
behind," leaving unchallenged the idea that "getting ahead" must mean increasing access to home ownership.

The Treasury-HUD report also suggested that it might be time to reassess the tax preference for mortgage interest, which at least opens up the broader set of policies (far beyond the mortgage guarantee giants) that artificially push people to own homes. This raises the question of what an owner/renter neutral world would look like, and what kind of legal regime (aka regulation!) would be required to make it work. (Actually, I think that we should adopt policies to affirmatively discourage individual home ownership, because of the problem of risk concentration. I will, however, leave that aside for now. One enormous step at a time.)

The conservatives who clamor for the end of Fannie and Freddie do so, I suspect, in the belief that a new world of non-guaranteed loans would leave "the free market" to decide who lives in a house and who lives in an apartment. My assertion that rental markets can work reasonably well, however, is based on having lived in rental housing that is well-managed and well-maintained. I know, from having rented as an upper-middle class professional in Manhattan and DC/Maryland, that it is possible to have corporate-owned housing that is not a nightmare. By contrast, I vividly recall my days as a graduate student in the Boston area, left to the tender mercies of a low-end rental market that left my permanently low-income neighbors living in apartments with frequent (and sometimes disgusting) interruptions in power, water, sewage, and so on.

The preference among liberal advocates for increased home ownership among the poor and lower-middle-class, therefore, is based on the bitter reality that landlords have every incentive to take advantage of their tenants. Among many other problems, the costs of moving make it more difficult for renters to move away from bad landlords (even assuming that better ones exist), making the market adjustment process imperfect, at best. Even higher-income people need to rely on access to courts and regulators to enforce recalcitrant landlords to fulfill their obligations. After being scarred by uncounted horrible experiences with renting, it is understandable that people would view home ownership as an escape, finally liberating them from having to deal with rapacious and unresponsive property owners.

This means that the new world of more widespread renting -- including, as it must, the renting of single-family homes, not just apartments in multi-unit buildings -- would have to be accompanied by careful regulations to protect renters (and, to be fair, honest landlords) from abuses by the other side of the rental relationship. "Getting the government out of housing" must not mean simply allowing existing contract laws to govern the rental market. It would have to involve a very deliberately chosen set of policies that would correct the severe market failures that are fundamental to the housing market, especially for lower-income people.

Even if we could create those rules -- and, given my increasingly deep skepticism about "behavioral" remedies as opposed to "structural" remedies, I am not saying that the result would be ideal -- an even more difficult question is what would happen during a transition from the current regime to the neutral regime. What to do about all of those people who bought their piece of the American Dream? What will happen to them? I will address that question in a future Dorf on Law post. 


\title{
Home is Where You Wear Your Hat
}

\author{
Thursday, February 24, 2011
}

http://www.dorfonlaw.org/2011/02/home-is-where-you-wear-your-hat.html

Last Friday, I revisited the owning-versus-renting question in housing. With the Obama Administration taking a surprising stance that home ownership might not be the be-all and endall of housing policy -- that it might actually be better for some people to rent -- it is natural to ask who might be included among those who should not rent. My answer (based in large part on the idea that people's financial well-being should not be tied up in a single asset that can precipitously lose value): There is a rebuttable presumption that no individual should own his or her own home.

As a first step (one that is much more aggressive than anything the Administration is proposing), I suggested that public policy should at least not artificially encourage people to own homes. Even changing the current pro-ownership policy regime would only be the first step in this process, of course, because of the widely and deeply held belief that owning one's own home is evidence of having "made it." Changing such attitudes is not easy, but eliminating the current pro-ownership policies would rather quickly undermine many people's taste for risking everything on a house.

What are those policies? The list really is too long to discuss in any detail in a blog post, but it includes federal mortgage guarantees (the focus of the Administration's concern in promulgating its recent proposal), the deductibility of interest on mortgages, the deductibility of state and local property taxes, the exclusion from taxable income of the gain on the sale of a home (which would otherwise be taxed only at preferential capital gains rates, anyway), the homestead exemption in bankruptcy (which has been abused in states like Florida, where bankrupt litigants put all of their money into lavish homes), and so on.

As I mentioned this past Friday, however, there is a huge matter of fairness involved in changing the underlying rules that favor home ownership: People who bought their homes under the current regime would take potentially enormous losses if the legal incentives changed. This is true of any legal change, of course, but it is an especially large problem in housing, simply because so many people are involved. Moreover, while the losses from any legal change can possibly be justified by saying that there are no guarantees in life -- that, for example, people who buy Microsoft stock do so knowing that their investments would lose value if the government takes a more aggressive stance on antitrust law -- the home ownership situation presents a much stronger case for mercy. Having spent decades convincing everyone that owning a home is not only financially savvy but practically required for entry into Heaven, it would be especially unfair for policymakers now to channel Otter from "Animal House" and say, in essence: "You f\#cked up. You trusted us!" [Movie fans will notice that the title of this post is from another favorite from my youth: "The Adventures of Buckaroo Banzai Across the 8th Dimension." I'm still waiting for the promised sequel.] 
The problem, of course, is not that the housing stock should intrinsically be worth less in the hands of corporate owners who rent to individuals than in the hands of individual owners. If anything, the economies of scale involved in coordinating maintenance (repairs, snow removal, grass mowing, and so on) could lead to a combination of lower net costs to live in a house and higher property values. The potential losses come from the removal of public policies that directly and indirectly commit public funds to inflating the price of houses. Most obviously, if we believe that the mortgage interest deduction's value is included in the price of a house (making a person who would have been willing to pay $\$ 500,000$ for a house willing to go to $\$ 600,000)$, then the removal of that subsidy will result in an immediate loss to current homeowners.

The textbook response to such a problem would be to compensate current owners for the policy change with a one-time lump-sum payment, making them whole and then letting the market go forward without policy-driven incentives to own. This would be enormously difficult, however, for the same reason that lending standards can be so easily manipulated: valuation is imprecise. Just ask any appraiser how easy it can be to make up a number. In the early 2000's, mortgage originators gleefully encouraged over-valuations, because they ultimately did not pay the price of those misjudgments. In a buy-out regime, with the federal government on the hook for the estimated losses, it would be especially tempting to game the system. (It would not be impossible to police this -- by, say, requiring look-back rules on subsequent sales under which federal payouts could be recaptured -- but I would not want to be the Inspector General for such a regime.)

The underlying goal here is to spread losses. (Arguably, however, some of the current rules should be changed in a way that concentrates losses, such as the homestead rules mentioned above. Taking this seriously would complicate matters even further.) The one-time buyouts would spread those losses by having the federal government initially cover the losses, which would thus be passed through to current and future taxpayers. If, however, we are not willing to concentrate the losses on homeowners, but we are too worried to nationalize the losses through the government, the next obvious place to look is shareholders. If there were a way to get the new corporate owners/managers of the housing stock to pay current prices for houses to make families whole, then to reduce the value of the housing stock by eliminating all of the subsidies later, the losses would show up in the form of reduced shareholder value. This would still cause pain to individuals (through, for example, reduced values of retirement and pension funds that have invested in real estate stocks), but the pain would presumably be more diffuse, with no one losing as large a chunk of their life savings because of the policy change.

Forward-looking investors, however, could unravel such a plan rather quickly. If the policy were announced in advance, the prices offered by corporate owner/managers would reflect the anticipated change in legal rules (adjusted for time value of money and risk), at least in the aggregate. The only alternative would be to pretend that no such plan was in the offing -- that the subsidies would continue for ever. That kind of clever plan would be nearly impossible to pull off, however, and it would also be subject to renegotiation under intense pressure from the new stakeholders.

If we are not willing to explicitly raise taxes to pay for the transition, and we are unwilling to 
make current homeowners pay, and we are not able to make future corporate owners pay, what is left? It is not enough to say that continuing the current regime is the cost-free alternative. We know from recent, bitter experience that the current system is not cost-free. The costs are hidden until it is too late (foreclosure crisis, financial bailouts), and they are sometimes worse than they need to be, because of market overreactions and the all-in character of too many families' financial investments in their homes.

The alternatives, therefore, are to adjust the rules to allow the current regime of subsidized home ownership to continue (with the adjustments designed to minimize the risks of concentrated losses and systemic crises), or to unravel the current regime slowly enough that the pain is tolerable. Nearly every politician favors the former, while I strongly prefer the latter. (The remaining political divide, of course, is driven by disagreements over how widely the subsidies should be made available, and how honest we should be about the implicit federal guarantees against systemic failure. Nearly all politicians, however, leave unchallenged the idea that home ownership is a high calling -- at least for most people.)

How boring is this? In the end, I am arguing for a radical re-ordering of society, to be carried out over decades in an orderly fashion. And I do so, knowing that it all could be reversed at any time. (In my defense, however, we are talking about undoing policies that have been in place for decades.) Surprisingly, the place to start might be where I began in one of my first DoL posts about the housing crisis: Point out to people that -- even with the pro-ownership subsidies in place -- owning one's home is not the financial boon that it is made out to be. Much of the current problem stems from people's belief that ownership is not only morally correct but financially wise. If we can disabuse people of that idea -- a process that will take time to unfold - then the costs of future policy changes will almost surely go down. 


\title{
I Feel So Broke Up, I Wanna Go Home
}

\author{
Friday, February 25, 2011
}

http://www.dorfonlaw.org/2011/02/i-feel-so-broke-up-i-wanna-go-home.html

As I clicked the "Publish Post" button yesterday, committing my latest renting-is-better-thanowning post to the eternal blogosphere, I felt a deep sense of unease. At the time, I thought that the unease was caused by my suspicion that I had wimped out. After years of boldly saying that individual home ownership is a bad idea and should be discouraged, I had confronted the transitional issues and flinched. How to change things for the better, I asked? Slowly change people's attitudes, perhaps over the course of decades, I mumbled. Wimpy, wimpy, wimpy.

My discomfort intensified as the day wore on. It soon became clear, however, that the timidity of my position was the least of it. In this post, therefore, I will describe two fundamental errors that infected yesterday's post. Both of them end up further supporting my policy preference (and one might even reduce the wimp factor), but the errors are important for reasons that go far beyond housing policy.

My first error was in describing the housing market and related markets in the stylized terms that one finds in economics textbooks, assuming away real-life complications and acting as if the basic economic models accurately apply to the issues at hand. The most obvious example of this was my blithe assertion that the stock market would immediately and accurately respond to information about future policy changes, adjusting prices to offset those future changes. The closest I could come to a nod of recognition toward the real world was to allow that the market's response would be "adjusted for time value of money and risk," which is actually an even stronger assertion that prices respond perfectly. While many economists point to financial markets as being the closest of all real-world markets to the textbook models, however, it should by now go without saying that financial markets have proven capable of deviating rather severely from what we see in the textbooks.

There was a very good comment on the post, from a reader who goes by the name Doug. Doug gently noted similar errors in my claims about how the prices of houses fully reflect the mortgage interest deduction and other pro-ownership policies, suggesting that I was at least overstating the effect of those policies on home prices. The direct implication of his observations is that I might not need to be so wimpy after all. The more weakly resale prices respond to policy changes, after all, the less we have to worry about current homeowners being hammered by a policy change to discourage home ownership, and the more quickly we can make the changes.

These are merely a few useful examples of broader problems, however. At the very least, they are another illustration of the dangers of reasoning arguendo. Rather than saying, "Assuming (against all reality), that the various markets related to housing work as they do in the textbooks

...," I said, "Because housing markets work as they do in the textbooks ... ." Even that reading, though, is far too generous. The import of my argument depended almost entirely on the validity of those assumptions. It was not a matter of being able to say that a logical outcome followed 
even if one stuck to the orthodox assumptions. The outcome was driven by those assumptions.

The first fundamental error in yesterday's post, therefore, was in allowing my traditional economics training to take over my brain entirely. Those who know me would find this at least ironic (and probably hilarious), given how much of my professional life is spent critiquing traditional economics. Still, given how often I have been baited with labels like Marxist, Communist, Socialist, anti-freedom, and so on, it is at least a change of pace to be accused (in this case, correctly) of being too much of a believer in textbook, market-oriented economics.

The second fundamental error in yesterday's post is even more troubling. At its core, my post framed the choice between the current pro-ownership legal structure and my preferred alternative proposal as a matter of removing unnatural policies and returning to an undistorted world where people's true preferences can play out in private, arms'-length transactions. (This is also an assumption in standard economics, but it is much less visible -- and much less widely understood -- than the more standard assumptions that allow the models to "prove" that markets are Paretoefficient.)

For example, I wrote that "public policy should at least not artificially encourage people to own homes." "Artificially"?! Where did that come from? Obviously, my implicit strategy was to say that the current policy regime is not only bad in terms of its outcomes, but that it is unnatural, a deviation from something pure. This only makes sense, however, if there is a natural baseline against which all other arrangements can be measured. As is acknowledged in the economics literature (and, even more clearly, in the philosophy of science literature), there is no such natural baseline. (I should add, however, that being in the literature has not translated into this concept being widely taught -- or understood -- in economics departments.)

This lack of a neutral baseline means that my argument cannot plausibly be defended as advocating a return to the mythical state of nature, a world where we respect peoples' preferences and get policy out of the the way of happiness and progress. My bottom line, after all, was that we need to change people's attitudes. In that way, I am engaging in what liberals like me are always accused of engaging in: Telling people what is best for them, because I know better. Of course, that is what policy analysis is (liberal and conservative alike), and I do it all the time. I wish, for example, that the vast majority of people would understand that the estate tax will never apply to them, and that they (and the entire society) would be better off if they embraced rather than rejected it. Similarly, I wish that people would come to understand the foolishness (as well as the inherent bigotry) of anti-immigrant and anti-Muslim biases. I wish that gay civil rights were fully recognized and protected, and that women's reproductive rights were not under assault. In short, I wish that whatever is "the matter with Kansas" could be cured.

Preferences for home ownership are no different, in that people are acting in ways that I think are ultimately self-defeating and broadly dangerous. Still, one might argue, is there not something artificial about policies to reinforce those preferences? Given how strongly people believe in the moral importance of home ownership, it is unsurprising that public policy supports those beliefs. Yet we still might say that it is inappropriate for public policy to affirmatively support one view of the good life over others. 
The problem with that assertion is that there is no "clean" baseline for public policy when it comes to housing (or anything else). We might look at the deduction for interest on home mortgages and say, "Well, that is clearly an add-on that supports the preference for home ownership. We can just repeal that provision of the tax code, and we will be closer to nature." But what about the failure to tax the consumption value of owner-occupied housing? Any "pure" definition of income or consumption would include this in the taxable base (because it substitutes for renting, which must be paid for out of after-tax funds), yet there is no code section to repeal.

One could still maintain that the tax code would be "purer" if we added a section to make it clear that owner-occupied housing should be taxed as consumption (and thus income). That, however, would undermine the idea that a simpler tax code (i.e., one with fewer sections) is a more natural tax code. More importantly, it assumes that the choice of tax base itself is somehow natural. If we did not have an income tax (or a consumption tax) and replaced it with a wage tax, owneroccupied housing would not be taxed at all. However, if we replaced the federal income tax with a federal property tax, housing would be taxed much more directly (and probably more heavily). And not having any tax at all is not a coherent baseline, because without government enforcement of property rights and contracts, there would be no market for either owning or renting homes.

In the tax area, this is now known as "the Murphy/Nagel point." The idea, however, extends well beyond the question of taxes. Government decisions about zoning, sewage districts, access roads, and so on, determine what kind of housing stock will even exist. And non-decisions are decisions. A city with no zoning laws, for example, is still dependent on the range of laws regarding real property, inheritance, nuisance, and so on that will be a necessary part of any gathering of humans living together.

Perhaps an even more obvious example of the baseline problem is in the area of immigration. What is the natural baseline for immigration, against which all other policies should be measured? Being against illegal immigration is no answer, because the issue is what the standard of legality should be. Is no immigration at all the baseline? Or is the non-artificial baseline a "no law/get the government off our backs" world that would amount to open immigration? That latter possibility, at least, would involve no government agents, no government spending, no licensing procedures, no prosecutions, and no apparent government involvement. Of course, the whole notion of being a nation means being able to say what is not part of that nation, so it would be rather odd to say that the natural path to maximum freedom in a country is to abolish the borders of the country.

In short, I framed my argument yesterday to appeal to the idea that we are currently doing something impure and distorted, whereas my supposedly more enlightened proposal would return us to a state of grace. I continue to believe that the current system is a worse choice than a system that would reduce or eliminate private home ownership. No set of policies, however, is the presumptive, non-artificial baseline involving no government intervention. As effective as it can be to frame policy debates as a choice of purity versus contamination, I should have known better. 


\section{If Renting Houses Were a Good Idea, Wouldn't It Already Be Happening?}

\section{Thursday, June 02, 2011}

http://www.dorfonlaw.org/2011/06/if-renting-houses-were-good-idea.html

There was more bad news about the U.S. housing market this week. After plunging from their peak in 2006, housing prices had stabilized over the last few years, even recovering a tiny bit as the economy continues to struggle. The latest data, however, show that those minor gains have all been lost, with April's prices hitting a new post-bubble low. Also, the latest numbers show that home ownership is at a several-decade low (although more than $60 \%$ of households still own their homes).

Naturally, experts and forecasters disagree about the prospects for the immediate future. The more optimistic group says that the market has finally hit its low, but that the recovery will be long and uneven. The pessimists say that there is still reason to believe that prices will plunge further. As prices have given back only about half of their gains since 2000, there is at least reason to worry that we have not reached a "natural bottom," whatever that might mean. In any case, no one believes that a boom is on the way any time soon.

Ever since the housing bubble burst, I have been pushing the idea that public policy should not be based on an ideal of individual home ownership. (The most recent post is here.) I have made similar arguments in teaching my various courses, usually in the context of discussing the mortgage interest deduction. There are many aspects to the argument, but my bottom line is that it is a mistake to encourage people to put their life savings into one asset, especially since renting can have all the advantages of buying, with none of the disadvantages. (Note that my argument merely coincides with the bursting of the bubble. Even in good times, I would argue that individuals generally err by owning their homes.)

People often misunderstand me to be saying that I want people to live in apartments rather than houses. While there is a strong anti-suburbanization argument to be made, that is not my point when I advocate renting over owning. My point, instead, is that the current housing stock should not be owned by the people who occupy it. Instead, institutional investors (private and, where appropriate, public) should own the housing stock, renting both houses and apartments to individuals and families.

While the usual understanding of the rental relationship is based on a single building -- with a superintendent managing the apartment building on behalf of a (usually absentee) owner -- it is now common for companies to own and manage multiple buildings across the country. The company that owns and manages my apartment complex in suburban Maryland, for example, is based in Rochester, New York. There is nothing, therefore, that says that the ownership or management of housing units must be limited to a single building or location. 
This means that, just as some companies choose to buy and manage rental buildings (with multiple units) in many locations, companies could buy and manage a portfolio of rental buildings that includes single-family houses. The advantages to this would include the economies of scale from centralizing maintenance (yard work, roof repair, and so on), which should give well-run companies an opening to offer rental prices that could easily compete with the typical homeowners-on-their-own approach to buying and maintaining individual homes.

Moreover, the housing bust has created a simple transition path to a world in which people rent single-family homes. The foreclosure crisis involves throwing people out of homes that they formally owned, with the mortgage company taking possession from people who really, really do not want to leave. The foreclosing company then holds an empty house that it is unable to sell in a market with fewer and fewer qualified buyers, none of whom is willing to take a risk in a sinking market. While some evicted former owners would not be able to pay even market rent, some would. Certainly, there would be situations in which people could pay rent on a singlefamily home as reliably as they pay rent on a three-bedroom apartment nearby.

The housing crisis thus has the additional perverse effect of raising rents on apartments, which are the destination both of former owners and scared non-owners (as well as people who, like me, simply prefer to rent). Millions of housing units sit idle, losing value through neglect and vandalism, while the people who lived in those units compete for traditional rental units.

All of this suggests that, setting aside my policy reasons for wanting fewer people to own their own homes (single-family homes or otherwise), there is reason to believe that there is profit to be made in turning formerly owned houses into rentals.

One of the more annoying misapplications of "market reasoning" is the idea expressed in the title to this post: If your idea is so good, it would already be happening. I have heard this applied to any number of different situations, from proposals for new scholarly journals to ideas about cell phone pricing. While such reasoning breaks down quickly upon inspection - amounting, after all, to the idea that nothing could ever change, because change would mean that what was replaced was inferior to the new situation, which utility-maximizing people would never have accepted -there is nonetheless a basic truth at work. An intelligent analysis of any proposal should include an assessment of why a good alternative is not already being pursued. If there is profit being "left on the table," why are greedy people not grabbing for it?

One possible answer here is that current policy pushes people to own their own homes. This, however, explains only why people generally try to own rather than rent. It does not explain why, in the midst of a historic housing crisis, people who can no longer own the house with the white picket fence are not renting it instead. Again, millions of units are empty (costing the companies that foreclosed on those homes billions in lost rental payments), and millions of people would like to occupy such houses. What is stopping the owners and the potential renters from reaching a mutually agreeable, arms'-length deal?

While there are surely policy changes that could (and, in my opinion, should) be made to make such deals more likely, it is a bit of a mystery why the business model that I am describing has not taken off. Of course, some experiments along these lines might well be underway, and I 
might simply be unaware of them. At the very least, there has been no reported trend in this direction, in a market that has been under close scrutiny for years.

Beyond policy barriers, however, it seems that both the potential landlords and the potential tenants are "choosing" to pass up good deals. From the potential landlords' perspective, there might simply be too much uncertainty involved in this new business model. Even with Corporate America sitting on trillions of dollars of cash, and with millions of people available to work for newly-created suburban home management companies, this might not be the time to experiment. It is even easier to imagine what is going on from the potential renters' perspective. They have no market power at all; and if they were to ask the foreclosing company for the ability to rent the home, they would be given the standard response: "That's not our policy."

Meanwhile, millions of people are being displaced, and the nation's housing stock decays. No matter the reason for "the market" having failed to innovate its way out of this mess, there are good reasons to change policies to correct that failure. 


\section{Why Have a Bad Landlord When You Can Owe Money to a Worse Bank?}

Friday, June 03, 2011

http://www.dorfonlaw.org/2011/06/why-have-bad-landlord-when-you-can-owe.html

In yesterday's post, I noted a somewhat mysterious non-trend in the U.S. housing market. With financial institutions holding millions of empty homes, which they seized from now-evicted households (who learned the hard way that owning a house is a very tenuous form of financial security), and with millions of people being forced to rent, there has been no evident move by profit-seeking companies to buy those houses and rent them to those people.

Even if banks do not want to get into the real estate management business, after all, there are already large companies that own and manage hundreds or even thousands of buildings in states across the country. This suggests that there are people who know how to manage rental arrangements in more than one apartment building. Why, I asked, would we not see at least a few of those profit-seeking companies (or some start-ups) buying up empty houses and turning them into rentals (priced to reflect the differences between managing single-family homes and multiunit buildings, not all of which would favor the latter)? Why are they "leaving money on the table," in the terms favored by some economists?

Given my pro-renting attitude, it was understandable that one reader responded to my post with a one-line email: "You probably can afford to rent from a good landlord." As I discussed in a post earlier this year (see the last four paragraphs here), I have experienced both good landlords and bad. It is, indeed, the more recent good experiences that give me confidence that rented housing can be well-managed and liveable. The bad experiences convince me that well-managed an liveable housing is not a given. I continue, therefore, to believe that any move away from home ownership toward renting, especially if (as is likely) such a move is dominated by lower-income people, must be accompanied by enhanced protections for renters, compared to the laws that currently exist in the U.S.

There is, however, a bit more to be said about the idea that renting is better than owning only if we can improve the regulation of renting. Any presumption in favor of owning is, after all, based on the notion that people are in a relatively safe and stable (and knowable) position when they own. If we are choosing between having a mortgage and paying rent (even assuming that prices have adjusted to take into account taxes, resale price risk, and so on), the intuitive picture is one in which the owner/mortgage-holder is inherently safer than the non-owner/renter. If I own my home, "they" cannot mess with me.

What we now know, unfortunately, is that homeowners are not nearly as safe as we once thought. Some people have lost their homes to foreclosure, only to learn later that the company that evicted them had no valid legal claim on the home. The biggest problem is the "robosigning" phenomenon, in which mortgage lenders filed incomplete and defective papers on 
millions of homes. There have also, however, been reported cases in which the company attempting to foreclose on a home simply had no legal claim at all on that home. Even so, those companies have actually been able to evict people from their homes, using the legal system to seize property that they do not own. Add to this the reports of mortgage servicing companies engaging in delays to put non-delinquent homeowners into delinquency (by, for example, telling them that a loan modification review is under way, and later evicting them because the mortgage is delinquent), and the range of opportunities to mess with people through the mortgage process become clearer.

Consider, however, a small example that seems to cut the other way. Earlier this year, I tried to exercise a clause in my rental contract that allows a renter to modify certain terms of the lease, if he does so within 30 days of occupancy. The office manager told me that there would be no problem. Days went by, then weeks. I asked what was happening, and the manager told me that the home office was generating the paperwork, which would arrive within two weeks. Another month passed. The manager began to ignore my emails. Finally, I talked to the manager's boss, who told me that there was no record of my request. Fortunately, by that time my situation had changed, so that the original lease term actually suited me better than the new terms that I had requested.

Until that point, however, I was obviously frustrated and angry. More than once, I even thought that this was reason enough to consider buying a place, to be able to avoid having to deal with such incompetent fools. I then thought about the alternative, and wondered just how much satisfaction I would get from a mortgage company that was, say, incorrectly charging a late fee. It was a bit like sitting on a stalled subway train, thinking about how much better it would be to be driving along in one's car, only to remember the traffic jams and carnage on the roads.

In short, owning a home is not governed by a clear set of laws on which homeowners can rely, in sharp contrast to the vicissitudes of renting. Both renting and owning involve individuals entering into complicated contractual relationships with relatively powerful counter-parties, where those counter-parties have the power to make individuals' lives miserable in countless ways. Renting puts one at the mercy of their landlord/manager. Owning puts one at the mercy of their mortgage banker/servicer (as well as their property tax assessor, the contractors who do not show up to do work when promised and who do shoddy work, and everyone else who performs the various jobs that a homeowner cannot perform on his own).

Even if I were not able to say that I have recently lived in (reasonably) well-managed rental properties, therefore, it is not necessarily true that the existence of bad landlords makes owning preferable to renting. As always, we need to look at the alternative. Bad landlords can do bad things, and bad mortgage companies can do bad things. The consequences of the latter can be much more devastating than the former (in that they can wipe out a person's life savings, and then some), while the frequency of the former can make renting a stressful and miserable experience.

Naturally, I strongly advocate better consumer protection laws (and enforcement of those laws) for both renters and borrowers. We must not forget, however, that there are victims of abuse in 
both arenas. As harmful as it can be to have a bad landlord, that does not guarantee that owning would be any better. 


\title{
Owning vs. Renting: Some Not-At-All-Defensive-No-Really Thoughts on Professor Hockett's Latest Post
}

\author{
Friday, March 02, 2012 \\ http://www.dorfonlaw.org/2012/03/owning-vs-renting-some-not-at-all.html
}

In a recent post here on Dorf on Law, Professor Robert Hockett discussed some important policy analysis and advocacy in which he has recently engaged (with co-authors), including a legislative proposal to help homeowners who are unable to stay current on their mortgages. Hockett's work is in that category of insightful analysis that seems screamingly obvious as soon as a smart person says it, but that was not being said at all until that person came along.

The starting point of Hockett's analysis is that troubled mortgagors can be usefully grouped into categories, and that different policies will be helpful for people who fall into the different categories. As he points out, "one size fits all" really makes no sense here. Until Hockett and his co-authors got to work, however, one size fits all was really all we were getting -- and it was failing miserably.

Here is my thumbnail summary of Hockett's categories of troubled borrowers: (1) People who really cannot afford to be homeowners, and who only ended up owning homes because they were pulled into the bubble of the 2000's; (2) People who could probably be homeowners in a normal market, but who need one-shot principal reductions from their mortgages to make it possible for them to be viable as long-term homeowners; and (3) People who are not in fundamental trouble, in terms of their long-term economic viability (and ability to afford a mortgage), but who are being harmed by perversely rigid mortgage rules that effectively treat good borrowers as deadbeats, threatening to dispossess people who are really in no more than passing financial difficulty.

Hockett et al. offer policy solutions for each group, with the "bridge loan" idea for the last group being the focus of his Dorf on Law post. As far as I can tell, all of his proposals are worthy additions to the policy menu.

So what is my problem with Professor Hockett today? He says that it is important to concede the existence of the probably-small first group (the people who never should have been encouraged to apply for -- and who certainly never should have been given -- mortgages in the first place), without "falling too quickly for the 'baby out with the bathwater' line taken by many who mistake the crisis for 'proof' that the American fixation on home-owning tout court is ill-conceived."

As regular readers of Dorf on Law know, I have been on a bit of a campaign to demonstrate that it is a bad idea for people to own their own homes -- or, at least, that home ownership is not the presumptively great idea that everyone thinks it is. I have been publishing posts on this general topic since mid-2008, with one of the most recent ones being a post last June in which I wondered why "the market" was not already solving the renter/owner imbalance. (Short answer: 
Markets are not as clever as some people think.)

Even though Professor Hockett was clearly not targeting me with his comment that I quoted above, he does raise some interesting questions:

First, are there people who believe "that the American fixation on home-owning tout court is illconceived?" Absolutely, and I am one of them. To me, it is amazing that we tell people to put all of their money into an undiversified portfolio. All of the supposed advantages of home ownership (neighborhood stability, building nest eggs, etc.) are achievable without putting people in this ridiculously risky situation. While I have conceded that there might be insurmountable obstacles to unwinding the mess into which decades of bad (though wellmeaning) policies have gotten us, I have no hesitation in saying that the American fixation on owning one's own home is -- to say the very least -- ill-conceived.

Second, is the recent foreclosure crisis "proof" of the ill-conceived nature of our housing preferences? Again, yes. At least, the crisis has made all too real the previously hypothetical dangers of undiversified investing. Of course, Professor Hockett's point is that the never-shouldhave-owned group is small, and that the rest of the homeowners can be turned back into stable homeowners, if only we can figure out ways to get through this crisis.

I agree with that, and I do fervently hope that we can figure out and implement methods -especially those methods that Hockett and his colleagues have devised -- to minimize the pain and loss of the current crisis. Still, even if we could minimize the damage from the crisis, that does not mean that it was a good idea to put so many people into mortgages in the first place. Even people who are not in any of the "troubled borrowers" categories on which Hockett focuses have suffered from the housing bust, with personal wealth being devastated, retirements delayed, and lives disrupted. And the rate of return on housing, over the long term, has been lower even than the return on simple savings accounts. The harm goes far beyond the losses by subprime borrowers.

If we were starting from scratch, I do not think that we would simply say, "If we could make sure that everyone who takes out mortgage can avoid default, then we should encourage people to own their own homes." We would need to be sure that there is an affirmatively good reason to encourage home ownership. It does not throw the baby out with the bathwater to look at a crisis and say that the underpinnings of the crisis were the attitudes that governemnt policy had reinforced.

Therefore, third, we must ask whether there are good reasons to keep people in their own homes right now. The answer to that, of course, is a resounding yes. Rent-to-own would generally be a bad idea, because it would simply put people on the path toward home ownership. What we need (both immediately, and in the longer term) are paths from ownership into renting -- where the houses to be rented are the very houses that people have lost to foreclosure. The good news is that the federal government has called for proposals to create just such a program.

The value of Hockett's proposals is that they take the crisis as we find it. The current situation will stabilize most quickly if we follow the advice to create, inter alia, bridge loans for the people 
in Hockett's third category. This, perversely, reinforces the policies that encourage home ownership. That is not a bad thing, however. Some of the people who view the crisis as proof that broad-based home ownership is a bad public policy objective understand what second-best thinking entails. The only thing worse than spending trillions of dollars over the course of decades, convincing people to own their own homes, would be to leave them hanging when they foolishly did as they were told. 


\section{Professor Hockett is to Professor Buchanan as a Zebra is to a Unicorn}

Tuesday, March 06, 2012

http://www.dorfonlaw.org/2012/03/professor-hockett-is-to-professor.html

In my post on Monday, I responded (only somewhat defensively) to Professor Hockett's most recent Dorf on Law post, in which he offered some extremely helpful thoughts on how best to handle the ongoing problem of mortgage foreclosures on U.S. homeowners. He described three categories of distressed borrowers, each of which calls for a different policy remedy. I continue to think that his analysis represents a major breakthrough that might allow us finally to make real progress on the foreclosure problem.

My complaint, such as it was, involved Professor Hockett's comment that some people (ahem!) might "throw the baby out with the bathwater" and claim that the foreclosure crisis proves that individual home ownership is a fundamentally bad idea. I do, in fact, believe that individual home ownership is a bad idea, and that the current problems at least strongly demonstrate some of the reasons that people generally should not be single-asset investors (which is what almost every homeowner becomes). Admitting, as I have in most of my posts on this subject, that there is quite a difference between starting from a fresh slate -- asking, in the abstract, whether we should enact policies that encourage, discourage, or a neutral regarding home ownership -- and trying to reverse a decades-old policy regime (no matter how ill-begotten), I suggested that there are ways both to respect and protect current home ownership and to slowly guide people out of the home ownership trap (for example, in what amounts to "own-to-rent" programs).

In his typically engaging fashion, Professor Hockett commented on my post as follows, in pertinent part:

"[A]greed!, even on the imprudence of net-worth-concentration in homes! In other work which I've not made much of in recent years owing to the crisis, I've worked to design hedging instruments (sometimes with old mentor Bob Shiller) meant to address this problem. More on that in the near future. One reason that I tend to favor that route over the rental route is that a sort of cultural path dependence - including a sorta civic republican political cultural heritage - seems to me apt to keep us fixated on owning. And, relatedly, home-owning seems in a way to 'ground' people in this country in a way less needful, perhaps, in other nations in which better established cultural patterns seem to do the necessary grounding."

Professor Hockett thus suggests that we can simultaneously keep people in homes, while overcoming my main objection to home ownership -- the risk of personal economic devastation for homeowners who need to cash out (e.g., to retire) when the market is down. If such protection is possible, then I certainly will be much more open to the pro-ownership argument.

Even so, this does strike me at least as a helpful reminder that there are costs to trying to keep the 
current system going. Without knowing the details of Bob's plan, I cannot guess as to its cost; but it is worth remembering that there is something on the other side of the ledger, to weigh against the costs of transitioning out of the ownership model. (As I have discussed, the biggest problem in any transition is how to deal with the loss in value of individual homes when the government stops subsidizing their price. In other words, am I not saying that we should prevent people from taking the risk of being economically devastated, by guaranteeing that they will be economically devastated?) Yes, it would be costly to move to a new system. But it would be costly to stay with the current system, and it would also be costly to move to a "Hockett Hedge," as it were. We are now down to an empirical question.

I confess, however, that I think I will lose the empirical comparison. The depth of our social commitment to home ownership is almost surely so deep that unwinding it would be much, MUCH more costly than any of the limping-along-with-the-current-basic-approach alternatives. I am arguing for a "purer" system, in an impure world that might have (probably already has) priced my system into irrelevance, at least over any reasonable time period.

That said, however, I should at least register some doubts as to Bob's stated reason for thinking that the current system is worth saving. He offers the suggestion that the cultural path dependence of home ownership is connected to civic republican virtues, by which I suspect that he means that people who own homes might be more committed and connected to their neighborhoods and (broadly speaking) to their local political systems, if they feel a sense of literal ownership in their community. He admits that this might not be necessary in other countries, where people might feel "grounded" even without being homeowners, but that it seems necessary here.

Along similar lines, a comment by Paul Scott on my Monday post describes the types of improvements that he has performed on his home, actions on his part that were almost certainly driven by his being the owner of the property, not a renter. He thus describes well how people will invest their time and efforts (and additional money) in their homes (and, as Professor Hockett suggests, ultimately invest in their communities) only if they feel invested in a formal sense in the property.

Although I find these arguments plausible, I do have my doubts. I have owned five homes in my life, none of them for more than 4 years. In each case, I was told from the word go that, if I had any plans to sell the house, I should NEVER do anything to the house that would personalize it, because that would make it harder to sell. Given that the median period of home ownership in the U.S. is only 6 or 7 years (and people know that they are not really rooted, merely by virtue of owning a home), it seems to me that there is every reason to believe that even homeowners will often refuse to invest in their homes and communities in the ways that the civic republican model describes.

On the other side of the story, I know that many people in major cities (especially New York) live in the same rental unit for their entire lives. If they know (as many apparently do) that they will not be moving, then they become just as involved in PTA's, local theater groups, and so on, as anyone anywhere in the country or the world. Therefore, this does not seem to be a difference of Americans versus non-Americans, but simply a matter of expected tenure. 
In an earlier discussion along these lines on Dorf on Law, a commenter pointed out that this point actually amounts to an argument in favor of rent control. Many people have told me that they do not feel as invested in rentals as in owned homes, because their landlord could either literally or effectively evict them at any time. In places where that is not true, people become ensconced, in both good ways and bad ways. One of the good ways is that they become better neighbors, and better civic republicans.

Even so, Professor Hockett is ultimately aiming to make his work as useful as possible to a current policy audience. His unique stripes show him to be somewhat exotic, in making policy suggestions that break from the common mold, and that require some government intervention that might generate some political resistance. Nonetheless, he is doing something that I am not: Thinking about how to solve today's problem, as soon as possible. I, on the other hand, am content to think about whether there is a big-picture fantasy world in which a better outcome is possible. Neither Professor Hockett nor I are plow horses, but we are different from each other. Which brings me back to the title of this post. 


\title{
Professor Buchanan Rejoins the Propertied Class
}

\author{
Thursday, May 03, 2012
}

http://www.dorfonlaw.org/2012/05/professor-buchanan-rejoins-propertied.html

Hypocrisy!! The State of Maryland recently registered a deed for fee simple ownership of land (on which a single-family home sits) to one Neil H. Buchanan. Granted, there are a dozen or so Neil Buchanan's in the world, including an English "Television presenter/producer, musician, guitarist, Actor" who once hosted a children's TV show called "Motormouth." There is also a mugshot of another Neil H. Buchanan here.

But there is no doubt that this deed was registered to the guy who teaches tax law at The George Washington University. How could this be?! Professor Buchanan has been on a years-long crusade to convince the world that individual home ownership is both individually risky and socially damaging. Of a countless number of posts on the subject, the most recent can be found here -- from only two months ago! He says that the mortgage interest deduction is a bad idea, that corporations should own single-family homes and rent them to families and individuals, and he offers other radical arguments that deny the importance of home ownership and the American Dream.

What is going on here?! First, yes, I closed on the purchase of a house last week. Second, no, I am not a hypocrite (at least, not in this regard). But, as Sen. Coburn so artlessly said of thenJudge Sonia Sotomayor, I "have a lot of 'splainin' to do." What gives?

If I had my way, we would never have developed the social norms that elevate the notion of individual home ownership into its current near-mythic status. People believe that home ownership is necessary to having stable neighborhoods, to promote financial stability, and so on. The problem is, it is all just not true.

Even if those positive social externalities were not imagined, however, the difference between owning and renting is, as an initial matter, simply a legal distinction. Especially for those with mortgages (who, as the saying goes, "are allowed to live in the house that the bank owns"), there is no fundamental difference between renting and owning. (Even for those without mortgages, the opportunity cost of buying a home with cash -- and thus holding that money out of other investments -- is the same as rent.) Everything else -- the conditions under which ouster is possible, and so on -- is part of the system of property law. Those legal differences are often of profound importance, but none of them need be connected to one type of occupancy and not another.

Nevertheless, our laws (certainly including the tax code) are consciously designed to encourage home ownership. Even if there need be no substantive difference between owning and renting, there certainly are many substantial differences under the current legal regime. Many people, therefore, argue that it is simply a matter of good financial planning for everyone to try to own their own home. In fact, a virtual sub-industry exists to convince people like my students (mid- 
20 's professionals) that they are not truly grown up unless they own a home.

One of the key arguments offered in defense of that absurd proposition is that the mortgage interest deduction is "the great middle-class tax break." In a way, that is a true statement, in that most people who itemize do so because they own homes. They reduce their tax bills by deducting their mortgage interest (and, under a different tax provision, their property taxes). The next step, however, is not true: Because of this tax break, middle-class people "throw away money" by paying rent to a landlord, rather than building equity in a house.

This is an empirical assertion, masquerading as a categorical truth. Even after taking into account the increased ownership stake that is part of each principal-and-interest monthly payment, and even after taking advantage of all tax breaks, it is still possible that renting is cheaper than owning. In fact, given that so many people are convinced that the better choice is always to own, the artificially reduced demand for rentals (which is the mirror image of the artificially increased demand for ownership) should systematically make renting cheaper than owning.

Before the recent financial crisis, we did not know how much damage could result from individual home ownership, in terms of the risks associated with a completely non-diversified portfolio. We now know that this, too, is a huge cost -- to both individuals and society -- of our obsession with home ownership. Foreclosures on a massive scale continue to haunt the economy.

But back to my new status as a homeowner. I have never told my students that there are no circumstances in which one should buy a home. The simple economic story that I told above -like all simplistic economic tales -- depends on several unstated factors. The most important of these is that there are reasonably deep rental and purchase markets for similar homes. In many cases, that is not true. Once I had chosen the town in Maryland where I wanted to live, I learned that there were almost no rental homes available. There were simply no apples-to-apples comparisons between renting and owning.

That, however, did not make buying the only choice. Even an apples-to-broccoli comparison is meaningful, within limits. If I had learned that the few rental options lacked some features that I might desire (large yards, for example), then I could decide how much more I was willing to pay (net of everything, including tax breaks) for those features.

Here is where the story became more interesting, under the particular facts that I faced. The net cost of owning a 4-bedroom, 3-bath house, on a relatively large lot, within easy access of the DC Metro, was actually less than the cost of renting a 2-bedroom, 1-bath apartment in the same town. I saved money, on a monthly basis, by buying a bigger place. Did not see that coming.

Of course, that is not the whole story. My financial portfolio is now heavily tilted toward one big asset. I could lose big, depending upon when I sell. There could be a toxic waste leak in the next town, which could make my neighborhood uninhabitable. Bad things do happen. For a tenured, middle-aged guy who loves his job and his location, however, these risks are about as small as they can be.

I continue to believe that public policy -- and popular mythology -- should not push people into 
home ownership. I also know, however, that home ownership under the current rules makes sense for many people. (Marriage also makes sense for many people -- but not for everyone.) Yes, my financial well-being is now somewhat more tightly bound with policies that I personally oppose. That, however, is true of many policies. For example, under my ideal income tax system, people like me would pay more than we do today. There is no hypocrisy there.

In the main, one makes choices not on the basis of what the rules should be, but as they are. The average law school graduate should not feel pressured to buy a home. No one should. For many people, however, it will make sense to buy rather than rent. If I ever need to sell, I will be happy that such people exist. 


\title{
$\underline{\text { Private and Public Bureaucracies: Home Ownership Edition }}$
}

\author{
Friday, May 04, 2012 \\ http://www.dorfonlaw.org/2012/05/private-and-public-bureaucracies-home.html
}

[Note to readers: This post begins with an anecdote that I thought was the basis for a Dorf on Law post that I wrote two years ago (roughly). I have not, however, been able to find that post in the archive, making me think that I might have imagined writing that earlier post. In any case, if the story sounds familiar to some of you, I assure you that you are not alone.]

In 2009, I received a notice from the New York State government, warning me that my state income tax delinquency from 2004 was about to be referred to a collection agency. Any such notice will make a person's heart skip a beat, of course. In my case, however, the initial fear quickly gave way to confusion. I had not lived in New York in 2004, so I could not imagine how I ended up with a tax bill from the state.

My next thought was that fixing the problem would be absurdly time-consuming and frustrating. Even getting in touch with a human being would be difficult, I thought, to say nothing of being lucky enough to find someone who might be helpful. (My opinion of the New York State government has always been especially low.) I imagined the worst kind of bureaucratic nightmare, with my credit rating ending up in the trash, and the state unwilling to give up on a bogus tax bill. I braced myself for a long, maddening fight.

To my surprise, however, I did find a helpful person, who was willing to speak with me right away. The problem was simple and understandable. As part of its regular procedures, New York (like most states) checks IRS filings to find people who should have filed state tax returns. I had moved to New York in early 2005. When I filled out my 2004 Form 1040 in Spring 2005, I had entered my new New York City address on the form, so that my 2005 forms would be sent to that address. New York's auditing software noted that my 2004 federal forms included a New York address, which kicked in an automatic deficiency computation. By the time that this process had run (a few years, for no apparent reason), I had moved to DC. New York State only found me again in 2009 , when I moved to Ithaca for my sabbatical. That is when they sent me the deficiency notice.

The solution was easy. I should send my full-year New Jersey state tax return from 2004 to the New York State tax department, to prove that I had not lived in New York during that year. Accordingly, I promptly sent in the appropriate copies and forms, and in short order, I received a letter from NYS canceling the tax delinquency. I was delighted, and life went on.

As I noted in yesterday's post, I recently purchased a house. I genuinely had not expected to be in the market for a new house, so I did not go through in advance the due diligence that one would normally hope to see from a borrower (checking one's credit rating for errors, etc.). But because I had done nothing that should affect my credit record, I proceeded on the assumption that my credit was pristine, and that financing would not be an issue. 
Wrong. The NYS tax delinquency was still sitting on my credit reports, from all three national credit rating agencies. My mortgage originator (an extremely good guy, and one of the most helpful and hyper-competent service professionals I have ever met) told me that the reduced credit score would result in a mortgage interest rate $0.25 \%$ higher than it would otherwise be, which adds up to tens of thousands of dollars over the life of the loan. No problem, I told him. I have the letter from NYS verifying that the delinquency was erroneous. I faxed that letter to the mortgage originator. Problem solved.

Wrong again. The credit agencies did not accept the letter from New York State. Instead, they wanted a "stamped" letter. Not having access to a nearby New York State government office that could stamp a letter (because I live in Maryland, hundreds of miles away), and lacking the luxury of time, I had to find an alternative. Happily, the Albany clerk's office responded to a conference call from the coordinating credit agency, with me on the line. The clerk not only verified that I had no tax delinquency, but she pointed out that the erroneous delinquency had been "vacated," which meant that "it never should have been." That is, it was not a valid delinquency that had been paid off, but a mistake that had been erased. Now, everything would go forward.

Wrong yet again. The credit agencies refused to accept this evidence, and they all refused to change my credit score. They said that they would allow me to authorize the release by New York State of information to them, which they would then validate on their own. The Albany clerk then told me that the credit agencies had been told many times over the years that this is illegal. The mortgage originator (the good guy in this story, along with his amazing assistant) then tried to get the credit agencies to accept a new letter that had arrived in the meantime from New York, this one with a stamp. That satisfied two of the three credit agencies. Unfortunately, the third agency was not only unsatisfied, but it initiated a 30-day audit of my account.

With the closing on the house set for the next day, we were left in a difficult position. Fortunately, the mortgage originator was able to cobble together a temporary work-around that (while not entirely risk-free) will almost certainly allow me to end up where I should have been in the first place, with no extra money out of pocket, net of everything. As of this moment, we are a little less than a month away from knowing what will happen next.

A few thoughts:

(1) While it might appear that I wrote down the gory details of these events for my own therapeutic purposes, my real purpose is to contribute a datum to an ongoing discussion about the nature of bureaucracy. Because this is turning out well for me, there is no anger to work through here. Indeed, I found myself both amused and even pleased as the process unfolded, especially when I realized that I had a blog post in the making. (Talk about twisted priorities!)

(2) In addition to the heroic mortgage originator, the other "good guys" in this story are the New York State bureaucrats (whom I had feared so much). They were (both at the initial stage of making the delinquency go away, and in the various dealings with the credit agencies) both professional and helpful. They were genuinely fulfilling their role as public servants, while upholding important legal protections and procedures. 
(3) The private credit agencies exhibited the worst kind of bureaucratic idiocy. The only similar experiences to which I can compare their bureaucratic intransigence are: (A) when I have had to resolve credit issues with cable TV companies, and (B) every single interaction that I ever endured with Harvard University's administration. There are unhelpful people everywhere, but the myth that public bureaucrats are somehow worse than private bureaucrats is surprisingly resistant to evidence.

(4) Upper-middle class people receive a lot of help, when a problem arises. Upper-middle class people who have law degrees receive even more help. Even without this odd problem with a phantom tax delinquency, the level of help that I received throughout the process was much better than anything I received when I was younger, buying less expensive houses, and not yet trained in the law. I shudder to think what happens to people who are not favored by the system. 


\section{What I Said ... What They Heard}

\section{Thursday, May 17, 2012}

http://www.dorfonlaw.org/2012/05/what-i-said-what-they-heard.html

Let us start with the obvious: Humans have well-known limitations on their capacity for perceiving and processing information. Those limitations can make it especially challenging for those who try to offer nuanced or complicated arguments.

For example, litigators who represent defendants in criminal trials say that a jury has to have someone to blame. Even if the legal question before them is whether there is a reasonable doubt that the defendant committed the murder, it turns out that juries will often (usually?) convict, if the answer is "no" to the following question: Is there someone else who seems more likely to have committed the murder than this defendant? That the evidence against the defendant is weak, mutually inconsistent, or lacking credibility apparently matters little. "My client didn't do it," in jurors' minds, can only be supported by proving that "This other guy really did it."

The combined roles of teacher, scholar, and pundit offer similar (though less immediately consequential) lessons in dealing with twisted and incorrect responses from listeners and readers. Saying, "I do not like X," does not necessarily mean that "I dislike X," because it is also possible for one neither to like nor to dislike X. This is all covered in Logic 101 (or, at my undergraduate institution, a course called "The Nature of Argument"), but the burgeoning sub-fields of psychology that feed various behavioralist explanations of behavior -- often revealingly called "cognitive distortions" -- offer evidence that real life continues to offer endless examples of people making logical errors.

None of which is news, of course. Still, it is worth remembering the broader phenomenon when confronted with specific examples of unjustified logical leaps. For me, a good example of such an error is offered by reactions to my recent decision to buy a house. I made light of this error in my post discussing that decision, but the basic error is still rather simple and seductive. I have been saying, for quite some time: "It is not true that everyone should own their residence." What many people have heard me say is: "No one should own their residence."

Of course, there are strong and weak versions of what I said. The weak version is merely that every decision is fact-specific, and thus a choice between buying and renting should be driven by the facts. While weak, that statement still has some real power, because it denies the conventional wisdom that says that -- especially because of the deductibility of mortgage interest and property taxes -- owning a home is always the preferred choice.

The stronger version of my argument is that it is more likely than not that the better choice will be to rent rather than to own. The basis for that stronger claim (as I noted in my earlier post) is based on simple economic theory: supply and demand considerations are likely to make applesto-apples own-versus-rent comparisons come out in favor of renting, rather than buying. Other factors might cause a specific situation to deviate from that global expectation, but the rebuttable 
presumption is that renting will dominate buying. My decision to buy a house was thus simply a case of the specific facts of a case leading to an unexpected conclusion.

Even so, I once received an email from a student that read as follows: "Professor Buchanan, I am going to be married this weekend, and I will be on my honeymoon next week. I hope that you don't have the same attitude about marriage as you do about home ownership, because I would like to be excused from class next week." Let us assume that this email was serious (which, based on other evidence not worth relating here, seems a safe assumption). What the student seems to have heard was that Professor Buchanan is against home ownership, which I never said. (In the next class meeting, without identifying the student, I admitted that I actually do have the same attitude about home ownership and marriage: Both can be great ideas, but there are plenty of reasons to suspect that social norms push far too many people into both home purchases and marriages that are bad ideas.)

So, is this merely a matter of my own inability to be clear? Maybe, but if so, I am not alone. In $\underline{\text { a }}$ blog post last summer, Paul Krugman wrote:

"I'm not the first person to notice this, but whenever you read conservatives trying to critique what they think the other side believes, you find them assuming that their opponents must be mirror images of themselves. The right believes that less government spending is always good, regardless of circumstances, so it assumes that the other side must always favor more government spending. The right says that deficits are always evil (unless they're caused by tax cuts), so they assume that the center-left must favor deficits in all conditions."

Regarding deficits in particular, I certainly receive the same illogical feedback that Krugman identifies. Moreover, this is not merely the reactions of unthinking anti-government ideologues. In a talk last Fall at a good law school, I found myself compelled to clarify that I $d o$ think that deficits can be bad (and, in other circumstances, good). I added: "I'm not echoing Dick Cheney's infamous statement that 'Reagan proved deficits don't matter.' " What I had said was: "The deficits that we have been running since 2008 are not a long run problem." What they heard was: "Deficits are never a problem."

This tendency of people to make unjustified leaps motivated the title (and, of course, the content) of one of my law review articles (from 2006): "Is it Sometimes Good to Run Budget Deficits? If so, Should We Admit it (Out Loud)?" My question was posed as a non-universal statement: "sometimes," not "always." Even so, if the answer to the question was "yes" (and it is, as post2006 events have demonstrated yet again), then it might still be dangerous to say so, if people were to hear me saying that deficits are not a problem at all, as a categorical (rather than a conditional) statement.

I ultimately concluded that it is worth taking the risk that people might misunderstand, because the consequences of acting as if deficits are always bad are so unambiguously awful. Even so, it is disheartening to be confronted over and over again with examples of how people jump to the "mirror image" argument.

Another of my law review articles (from 2009), "What Do We Owe Future Generations?" skeptically confronted the repeated-ad-nauseum assertion that we must reduce deficits "for the 
sake of our children and grandchildren." Looking at projections from the Social Security Administration (the same projections that are used to try to convince people that the Social Security system is going bankrupt), I showed that the income levels of people living in the US 75 years in the future are forecast to be from two to four times higher than today's (inflationadjusted) income levels, on average. Further, I argued that the inter-generational lens is unhelpful in assessing what is ultimately a claim about distributive justice.

What I said, therefore, was: "Future generations are apparently going to be doing rather well (assuming that average income levels are what matter), so we need not form policy based on the ill-informed notion that we are impoverishing future generations." Even so, more than one colleague has said to me words to this effect: "But as you said, Neil, we shouldn't worry about future generations, right?"

In a way, that comment is at least partly correct: I did argue that inter-generational comparisons are not the right way to think about distributive justice, meaning that I arguably said that we should not worry about future generations qua future generations. Yet that is ultimately not the point, because I certainly never argued that we should not worry about how policies will affect people in the future. Moreover, some listeners seem to have heard me say that there is never anything to worry about, because of the forecasts that I cited. This would be like hearing someone say, "We don't need to turn the steering wheel to the right, because the road ahead is straight," and hearing, "We need to turn the steering wheel to the left" (or perhaps, "We don't need to steer at all").

Which brings me back to Krugman's reaction to this kind of logical error. Describing his conservative antagonists, Krugman wrote: "What seems beyond their intellectual range is the notion that other people might have subtler beliefs than their own. Keynesianism, in particular, is not about chanting 'big government good.' " While I certainly agree that liberal deviations from "Deficits bad!" are almost always met with "So you LOVE deficits, don't you?!" there is plenty of evidence that people are often making these errors for non-ideological reasons. My experiences with colleagues' comment re my work on future generations, for example, cannot be explained through a liberal/conservative framework, nor can the misreading of my comments about home ownership. There is something larger at work here.

So, what I just said was: "People often hear non-categorical statements, and incorrectly interpret them as categorical statements." I hesitate to imagine what some people will hear. 


\section{Leveling Up and Leveling Down: A (Probably Tenuous) Connection Between Home Ownership and Gay Marriage}

Friday, June 8, 2012

http://www.dorfonlaw.org/2012/06/leveling-up-and-leveling-down-probably.html

I am currently attending the Law \& Society Association's annual meeting, which began on Tuesday and ends today. This past Monday, the day before the larger conference began, the FemTax Working Group -- a new international collaboration of tax scholars whose work is informed by feminist legal theory, which was recently created by Asa Gunnarsson, Ann Mumford, Paloma de Villota, and Kathy Lahey -- held a one-day conference on "Feminism, Taxation, and Fiscal Policy." The full-day event was a testament to the importance of bringing together a global group of scholars, to think creatively about important issues, and especially to do so in a way that highlights feminist concerns.

One presentation at the FemTax conference especially caught my attention. Lily Kahng, a tax law professor at Seattle University (and a top-notch intellectual) offered some preliminary thoughts on a new project that she is developing. She is beginning to investigate the gendered aspects of the policies that encourage home ownership in the United States, thinking about how our policy choices in the area of housing have the effect of favoring men over women (just as they tend to benefit the wealthy over the non-wealthy, and whites over non-whites). I will leave aside for now the reasons for these unfortunate outcomes, but the evidence is overwhelming.

Professor Kahng shares my skepticism about the entire pro-ownership housing policy regime. Putting people in the position of preferring an undiversified portfolio seems perverse, especially when so many middle class people have NO other financial assets at all. Still, the current policy regime does shovel money into the hands of homeowners. For those who are not forced to sell when the market turns down, the financial advantages of home ownership are substantial.

Listening to Lily's comments, I made a quirky logical connection. (I confess that making odd connections like this is not unusual for me.) As I thought about the question of whether we should put more poor people into owner-occupied houses, or instead move more non-poor people out of owner-occupied houses, it suddenly struck me that we might be looking at another example of the "leveling up or leveling down" question.

That question was most famously raised in the Supreme Court's 1971 Palmer v. Thompson case, in which a majority of the Court held that the city government of Jackson, Mississippi did not violate equal protection by closing the city's pools, rather than integrating them. If the choice is "everyone gets it, or no one gets it," the Court held that there was no equal protection violation when the city decided that it would rather that no one be able to swim in public pools, rather than having whites and blacks swim in the same water.

As many readers know, this logic has recently been applied to the gay marriage debate, in which 
some apparently well-meaning people have suggested (as I noted in a recent Dorf on Law post) that the government should simply "get out of the marriage game." Doing that (leveling down), however, would validate the animus against gays that apparently motivates many opponents of gay marriage, who refuse to extend marriage to everyone (leveling up). Leveling down is based on the idea that some people hate gays so much that they would rather that no one have it than that everyone have it.

As a matter of first principles, we probably would not invent marriage, if it did not already exist. There are many problems with the institution, many of which have not been fixed after centuries of trying. At the very least, we would not have developed laws and social norms that push people into marriage. Yet here we are, in a world where singles are often treated as social rejects, oddities who should try harder to find their one true love. In that world, where marriage is an expected part of life, leveling up is essentially the only option. Jackson, Mississippi might have been willing to close its pools, but Americans are not going to stop getting married (and taking advantage of the legal and social incidents of marriage) simply because some single (gay and lesbian) people want in on the advantages of legal marriage.

Which brings me back to my campaign against home ownership. As an initial matter, we should not have pushed people into home ownership. Because we have, however, we must either figure out a way to level down (remove the incentives to home ownership, or even eliminate it as a legal option) or level up (bring the advantages of home ownership to everyone).

I hasten to add that the dignitary aspects of the two sides of my analogy are completely different. That is, the consequences of leveling down in housing are mostly financial, whereas the consequences of leveling down in marriage are a matter of human dignity. The analogy (like all analogies) is thus incomplete. Even so, the difficulties in imagining a fair way to unwind the policy regime favoring home ownership -- especially in a way that does not destroy the net worth of people who currently own homes -- make it nearly impossible to imagine how we would go about eliminating the pro-ownership rules and norms. Similarly, it is nearly impossible to imagine people giving up on government recognition of marriages.

All of which brings me back to a Dorf on Law post from earlier this year, written by frequent guest blogger Professor Bob Hockett. In the best-titled blog post ever, "Nest Eggs and Nests: A Brief Meditation on Neil Buchanan, Alexander Hamilton, Thomas Jefferson, Arrow Securities, Unicorns, Zebras, Dogs, Fire Hydrants and ... Oh Yah, Mortgage Relief," Bob offered a path to leveling up. Essentially, he is engaged in the difficult work of taking an inherently bad idea (universal home ownership) and making it work as well (and as fairly) as it can.

Professor Kahng's project could enrich this investigation in profoundly important ways, by making sure that we understand just how unfair the current system is for women (and other historically disfavored groups), exposing the hidden gendering of the home ownership regime. Although she currently is still in the leveling down camp, based on the completely defensible belief that we should figure out a way to pull apart the cult of home ownership, I am hoping to convince her at least to consider how her analysis could make a pro-ownership system more fair.

As for me, I readily admit that my revised view on policies toward home ownership coincides 
with my purchase of a home. Cynics might suspect that where I stand is partly determined by where I sit (and sleep). I can only say that the sticking point in my campaign against home ownership all along (see, e.g., here, long before I decided to buy a house) was the transitional question -- trying to discourage home ownership while honoring the investments that people have made, in good faith, in their versions of the American Dream. Having now concluded (at least tentatively) that there is no way to make that transition, I think it is important to figure out how to go in the opposite direction, to reach a fair result. But if I am to be accused of hypocrisy or opportunism, I can understand why.

The important thing is to understand that the best way forward might be to accept that we are stuck with a bad initial idea. If we can get others to assist Professors Hockett and Kahng in thinking through ways to help all people benefit from home ownership -- and to protect them from the very real risks to which home ownership exposes vulnerable people -- then we can make progress. I, for one, am willing to consider that I should stop obsessing over a ship that has long since sailed. 


\section{The (Somewhat) Hidden Costs of Home Ownership}

\section{Friday, June 15, 2012}

http://www.dorfonlaw.org/2012/06/somewhat-hidden-costs-of-home-ownership.html

As regular readers of Dorf on Law know, I have been doing quite a bit of thinking over the last few years about the owning-versus-renting question, in terms of personal residences. (Actually, that question is equally applicable to vacation homes, automobiles, and so on, where the details are different in each case. My strong -- though rebuttable -- presumption in every case is NOT to own.) Having reluctantly come around to an odd sort of pro-ownership position -- both as a policy matter (where I have recently concluded, in essence, that we as a society should encourage home ownership for all or for none, and it is impossible to see how to eliminate the many encouragements to own), and as a personal matter (having bought a house of my own in April) -- this seems like a good time to think about what we must do to make meaningful applesto-apples comparisons between owning and renting primary residences. One can think in the abstract about these issues, but after living the reality again even for only a month or so, I am here to report that the world can look quite different from this side of the divide.

In response to my post announcing my purchase of a house, a former student wrote in a comment: "Best of luck with the new home. I will appreciate any updates to your analysis of 'cheapness' once you have to account for rapidly growing lawns and towering leaf piles as an owner rather than renter!" That comment was in response to my claim that the net-of-everything cost of a rather spacious house in a Maryland suburb of DC was, much to my surprise, significantly less than the cost of a nice 2-bedroom apartment in (a much less nice part of) the same town. Indeed, this question goes far beyond the issue of lawn care.

When I sold my last house (in South Orange NJ) to move into an apartment in Manhattan, I marveled at the extreme economies of scale that were available in a high-density living arrangement. Nobody had to shovel sidewalks in winter (back when the Northeast had winters), saving themselves not only time and effort, but trips to emergency rooms (to treat the inevitable victims of over-exertion) and sometimes even morgues (for those who could not be brought back). Although my phrasing here is admittedly flippant, my point is serious. Individualized work effort has many upsides (exercise, personal fulfillment, and so on), but it also has hidden and unappreciated costs. Division of labor puts the people who are most willing to shovel snow - and who are, therefore, more likely to be properly equipped, both physically and in terms of machinery -- in the business of shoveling snow, and everyone else out of that business.

This might seem like an unfair comparison. After all, the difference between South Orange and Manhattan is not just that people generally own in the former but rent in the latter. The bigger difference is that Manhattan has no yards, no private sidewalks, and virtually none of the items that people would need to care for personally. Maintenance of the common areas is understandably farmed out, via management companies, and so on. 
That does not, however, solve the deeper question. As I have argued many times, there would be nothing (as a logical matter) stopping a management company from owning all the houses in South Orange, renting those houses to families, and then providing maintenance services as part of a rental agreement. This would take advantage of the division of labor that economists have loved at least since Adam Smith, thus reducing the time and effort necessary for any individual homeowner to mow her own lawn, shovel her driveway, and all of the other things that homeowners now routinely take on as a matter of course.

What one cannot truly appreciate until one spends a few weeks in the midst of the reality of home ownership, I think, is just how much of the economy of scale involves a reduction in transactions costs. Without a management company to do it for them, homeowners individually have to figure out how to find the best alternative to expending their own time and effort. This means finding individual contractors, calling them, having them come to the house, haggling over prices, hoping they come to do the work when promised, hoping they do the work well, and paying them. (And later, perhaps, suing them.)

This is bad enough, even for the regular maintenance issues that homeowners face, like lawn care and house cleaning. The internet is helping, too, with the emergence of sites like Angie's List (the existence of which amounts to a group primal scream: "How the hell are we supposed to know whom to hire?!"). Even so, if a person (like me) were attempting to construct an apples-toapples comparison of owning versus renting, would that person actually remember to include these regular maintenance costs on the owning side of the ledger? (I did, of course. Occupational habit.) And of those who did remember, how many would adjust for the search and other transactions costs described above? And how would one even put a number on them? (I did not even think of this in advance, and I still cannot figure out how to do so.)

Now consider the less-than-regular costs of home ownership, which is an entirely different set of issues that renters never have to consider. First, there are the upfront costs involved in the purchase of the home. How does one distribute closing costs over the period of home ownership, when one is unsure how long that period will be? Then, there are the big, occasional maintenance items. The roof of every house has to be replaced on a periodic basis, as do furnaces, sidewalks and driveways, windows, some pipes, and so on. Some repairs will occasion decisions to improve the home, but it will be unclear how much of the money spent will show up in the resale price of the house. (The maintenance-versus-improvement divide is a knotty issue in tax law, too.)

Readers who own their homes are surely smiling wanly at this point. I am hardly describing something new (to them, or to me, given that I owned five homes before buying my current place). That, however, is the point. We limp along in a bizarre world where people spend untold amounts of time dealing with window salesmen, cleaning services, real estate agents, lawn services, roofers, pavers, handymen, and every other kind of individual contractor. Cocktail party conversations and sitcom plots are rife with horror stories of contractors who make homeowners' lives miserable. By contrast, renters benefit from a system in which they do not have to worry about how old the roof might be; nor do they have to shop for a plumber if the pipes burst. 
That is not to say that rental management companies handle these things uniformly well. Far from it, of course. But that, too, is part of the point. The uncertainties on the renting side ("Will I have a super who actually responds when I have no hot water?") are nearly impossible to compare with the uncertainties on the owning side.

Finally, consider an issue that another commenter on my earlier post raised -- a point that has nothing at all to do with maintenance issues (even broadly construed). Because home loans are subject to amortization, the net cost of home ownership goes down over time. How can that be? Say that a person buys a house for $\$ 500,000$, with a $\$ 400,000$ mortgage. The monthly payment on a 30-year fixed-rate loan, at $4.5 \%$, is just above $\$ 2000$. In the first month of the first year of the loan, $\$ 1500$ of that is interest, and the rest reduces the principal on the loan. Because of that reduction in principal, the fixed monthly payment gradually becomes more tilted toward principal, and less toward interest. The first month of the second year of the loan, the split is $\$ 1475$ for interest, and the rest principal. In the first month of the fifth year, just under $\$ 1400$ is for interest. In the tenth year, $\$ 1240$. In the twentieth year, less than $\$ 800$ is being paid toward interest, and the remaining $\$ 1200+$ is increasing the equity in the house.

Because equity is equivalent to savings, it is not a cost of home ownership. Indeed, many people consider building equity to be the major benefit of buying a house. (Issues of financial diversification arise here, of course.) This means that the net cost of owning a home goes down over time. Adding to the uncertainties of how to spread the initial closing costs and infrequent (but predictably periodic) maintenance costs, therefore, is the reduction in interest cost as the time of ownership rises.

Obviously, this only scratches the surface of the issues that one could discuss, both general and specific, with regard to owning and renting. The point is that the confidence with which I (and many other economists) wave away concerns about "minor" issues like transactions costs is, especially in the housing context, truly baffling. As a personal matter, I continue to be amused by it all, managing to maintain my equanimity as I deal with yet another contractor who is supposed to be at my house at 10am tomorrow (but who knows, really?).

My bottom line is to say that my former student was right to wonder whether I was really taking everything into account, when I blithely said that the net-of-everything cost of buying was, in the specific circumstances that I faced, clearly in favor of owning. I still suspect that it was, but even as someone with so much hard-won experience, I now see that it was surprisingly easy to ignore many of the hidden non-joys of home ownership. Many are temporary, and many will become manageable with familiarity, but they are still costs on the side of owning. As a policy matter, if we are going to push even more people into home ownership, this is another set of issues that deserves serious study. 


\section{Wasted Talent and the Middle Class}

\section{Thursday, August 09, 2012}

http://www.dorfonlaw.org/2012/08/wasted-talent-and-middle-class.html

Late in the Spring of this year, I posted some thoughts challenging the common presumption that government employees are all unhelpful bureaucrats, while private companies' employees are the essence of efficient, responsive servants of the customer (who is, of course, always right). Upon even a moment's reflection, all of us can think of examples of private bureaucracies and individual private bureaucrats who are worse than anything we might find at the Department of Motor Vehicles or the Post Office (to cite the two bogeymen of anti-government zealots). Name your health insurer, and you have almost certainly also named the least responsive bureaucracy that you will ever face.

As part of that post, I noted that there are also (unsurprisingly) many very good and talented people working in both public and private bureaucracies. These people often make things happen through sheer force of will, and with great effort and application of creativity and knowledge, for no immediate gain to themselves. For lack of a better term, we might even say that these people have -- gasp! -- pride in their work. From a purely economic standpoint of individual maximization, this is not easy to explain (unless one simply cheats and says that "pride in work" is part of an individual's utility function, which tautologically explains away the mystery that these people are acting in ways that do not appear to have any connection with classic economic incentives).

The dramatis personae in the particular story that I was telling back in May were the people whose job it is to process mortgage applications and complete the sales of houses to private individuals. This includes a very large number of people, from the mortgage originators themselves, to the various bank employees who have to coordinate with the mortgage companies to exchange sensitive financial information, to the people at the credit rating companies (the villains in my particular story), to the various house inspectors, to the real estate agents, to the people who handle all of the paperwork at the closing. And those are only the people with whom a buyer actually has contact. There are surely many others who are also hard at work every day as part of the house-buying industrial complex, but who are invisible to the public.

This army of dedicated people is, to a very significant degree, the people who still make up the middle and upper-middle classes in this country. Realtors, especially those who work in upscale suburbs, are probably well above middle class, but not truly wealthy (other than the owners of some agencies). The others are all doing jobs that require (and make good use of) college educations and beyond, because the transactions are complicated and need to be processed in ways that are required by our legal system. It is not rocket science, but it is still very skilled, specialized work.

As regular readers of Dorf on Law know, I have been writing extensively over the last few years about the downsides of our obsession with individual ownership of houses and condos. (Most 
recent post here. My original post, four years ago this month, is here. Other posts are too numerous to list.) For reasons that I have described at length elsewhere, my bottom line is that there is a great deal of waste (and needless financial risk to middle-class people) caused by the over-investment in house purchases by individuals.

What is the alternative? As a broad matter of long-term social planning, it is almost certainly essential to de-suburbanize America -- or, at least, to stop further sprawl. There is now plenty of evidence that urban environments can offer an extremely high quality of life, and people are moving back into cities in large numbers. As an immediate matter, however, I have offered the observation that it is quite possible to have a non-ownership approach to housing, even when the housing stock consists mostly of detached, single-family homes with yards.

The basic idea is that management companies could buy up single-family homes and rent them out to people who might otherwise buy houses or rent apartments. (The Obama Administration has, in fact, issued calls for proposals to encourage such purchases of the abandoned and foreclosed homes that still sit empty, years after the housing bubble burst.) Those management companies would then run consolidated office and maintenance operations, allowing people to rent houses for less than it would cost to own and maintain a home as an individual. (One would also hope that these rental arrangements would include contractual terms that will involve a wider range of choices than most current rental contracts provide. Probably the most important change would be to offer leases of more than two years, so that people could have the same level of planning certainty that ownership currently provides.)

Why are these office and maintenance operations likely to be much less expensive than individual ownership? For the rather straightforward reason that most of the bureaucratic infrastructure in the house-buying industry is ultimately so unnecessary. Title insurance is only the tip of that iceberg. Realtors themselves, of course, also represent a rather large "economic rent" that would all but disappear in a rental-based economy. Much of the rest of the private and public bureaucracy supported by home purchases would also become unnecessary.

Even the operations that would still be necessary under a rental-based system would be subject to economies of scale. In a recent post, I offered a quick look at some of the crazy wastes of time and money that owners of houses endure, which could be handled much more easily by, for example, having one office send out plumbers as needed.

As we learn in elementary macroeconomics (based on even more elementary accounting principles), however, one person's cost is another person's income. Therefore, reducing costs means reducing incomes. The well-educated people who, in this view, are wasting their talents processing individual mortgage applications will be eligible to apply for "non-wasteful" jobs in management offices of rental companies. They should not, however, expect to earn nearly as much money as they currently earn. Reducing costs (and thus incomes) is the whole point of the exercise.

To a large extent, therefore, we are looking at another example of the "big box store" effect. There used to be small, family-run hardware stores. (If you are old enough to remember that Howard Cunningham's hardware store provided the middle-class lifestyle enjoyed by Marion, 
Richie, Joanie, and (for one season) Chuck, raise your hand.) Now, those stores have been almost completely obliterated by the big-box stores, which pay their employees low wages and minimal benefits.

Many economists like to believe that the talents of the educated, displaced workers will not ultimately be wasted. The hollowing out of the middle class over the past generation or so, however, suggests that this might not work as well as the textbooks claim. Surely, other important factors are at play here, especially the assault on organized labor since 1980. Even so, evidence is accumulating that suggests (to say the least) that we should be hesitant to destroy middle-class jobs without knowing where those people will land, and how much they will earn.

It is, therefore, at least possible that my personal holy war against individuals owning their houses is misguided in a very broad sense. It seems perverse to say that we need to tolerate "inefficiency" in the name of protecting the middle class. Yet that might well be the case. It might even be a good reason to question our notions of what constitutes efficiency itself. 